\title{
Abolir la ley de castas: Mérito, masculinidad y el problema del color en el movimiento liberal de Puerto Rico, 1873-92 ${ }^{1}$
}

\author{
Jesse Hoffnung-Garskof \\ Departamento de Historia \\ Universidad de Michigan
}

\begin{abstract}
Jesse Hoffnung- Garskof, "To Abolish the Law of Castes: Merit, Manhood, and the Problem of Colour in the Puerto Rican Liberal Movement, 1873-92," Social History 36, no. 3 (August 2011): 312-342.
\end{abstract}

Traducido por Juan R. Hernández

Este artículo rastrea la participación de tres hombres de bajo nivel social en la evolución de las políticas liberales en Puerto Rico durante las últimas décadas del gobierno colonial español. Particularmente, examina cómo Ramón Marín, Sotero Figueroa y Francisco Gonzalo (Pachín) Marín-hombres que, entre otros "defectos" de nacimiento, poseían además antepasados africanosnegociaron los sistemas de exclusión social que operaban en Puerto Rico en las décadas de 1860 y 1870 para convertirse en personas con una posición pública modesta, escritores y miembros de movimientos abolicionistas y partidos que buscaban reformas coloniales. Para la década de 1880, los tres escribían y publicaban sus obras en Ponce, una ciudad en la costa sur de Puerto Rico que funcionaba como un importante canal comercial tanto para la exportación de azúcar como de café. Ramón Marín era un maestro de escuela y dueño de una imprenta, el Establecimiento Tipográfico "El Vapor”. Figueroa y Pachín Marín

1. Quiero expresar mi agradecimiento a los siguientes colegas por sus cuidadosas lecturas y útiles sugerencias: Paulina Alberto, María del Carmen Baerga, Sueann Caulfield, Marie Cruz Soto, Astrid Cubano Iguina, Eileen Findlay, Josep Fradera, Miriam Jiménez-Román, Christopher Schmidt-Nowara, Agostina Allori, Lenny Ureña, y al referato anónimo de Social History. 
eran miembros de la clase de artesanos; ambos trabajaban como tipógrafos en "El Vapor" y en otras imprentas. Los tres fueron los autores de un grupo extraordinario de textos liberales, tanto periodísticos como literarios, que han sido mayormente ignorados. Estos textos, así como las vidas de Figueroa y los Marín, ofrecen una perspectiva única sobre el escenario político y social del Puerto Rico urbano en los últimos años bajo el control español. Estos escritores de ascendencia africana mezclada se involucraron con, trataron de reformular e incluso impugnaron abiertamente las ideas de clase y raza expuestas por los intelectuales patricios más reconocidos, como Alejandro Tapia, Rafael Corchado, Luis Muñoz Rivera y Salvador Brau. Aunque los reformistas patricios de Puerto Rico nunca buscaron imponer una política abierta de segregación y supremacía blanca, como sí lo hicieron sus contrapartes en los Estados Unidos, terminaron organizando campañas contra el vagabundeo, la ocupación informal de la tierra, ciertas enfermedades y la prostitución, que tenían como blanco aquellas poblaciones percibidas como problemáticas debido a su clase, casta y género. Estos hacendados y profesionales adinerados celebraron la "cordialidad" que existía entre las distintas clases y grupos raciales en Puerto Rico, pero tenían muy poco o ningún interés en promover la igualdad de clase o la igualdad racial. Por el contrario, la celebración de la simbólica "gran familia puertorriqueña", una familia que incluía trabajadores, afro-puertorriqueños y pueblos indígenas, ofrecía un modelo jerárquico de armonía social, basado en el poder patriarcal y en la riqueza de descendientes españoles. Recientes estudios académicos, históricos y literarios, ofrecen una mirada crítica y tajante de este discurso de paz social y racial, entendiéndolo como una forma de silenciar las discusiones sobre la discriminación racial y de clase en Puerto Rico ${ }^{2}$.

Sin embargo, con la excepción de algunos trabajos destacados sobre las ideologías opositoras de los trabajadores urbanos y los campesinos, los historiadores aún no se han preguntado cómo los plebeyos, especialmente aquellos de ascendencia africana confirmada, comenzaron a dialogar con la ideología liberal, tanto con su discurso de paz social como con su naciente discurso anticolonialista. Esta ausencia es especialmente notable debido a los considerables aportes que han proporcionado los estudios de las castas pardas en otras partes del gran Caribe. Artesanos, oficiales de milicias y escritores pardos adopta-

2. Véase, por ejemplo, Tomás Blanco y Arcadio Díaz Quiñones, El prejuicio racial en Puerto Rico (Río Piedras, Puerto Rico: Ediciones Huracán, 1985); Jorge Duany, The Puerto Rican Nation on the Move: Identities on the Island and in the United States (Chapel Hill, NC: University of North Carolina Press, 2002); Lillian Guerra, The Puerto Rican Nation on the Move: Identities on the Island and in the United States (Gainesville, Florida: University Press of Florida 1998); Francisco A. Scarano, "The Jíbaro Masquerade and the Subaltern Politics of Creole Identity Formation in Puerto Rico, 1745-1823", American Historical Review, C1, 5 (December 1996); Eileen Suárez Findlay, Imposing Decency: The Politics of Sexuality and Race in Puerto Rico, 1870-1920 (Durham, NC: Duke University Press, 1999); e Isabelo Zenón Cruz, Narciso descubre su trasero: el negro en la cultura puertorriqueña (Humacao, Puerto Rico: Editorial Furidi, 1974). 
ron y ayudaron a construir lo que Marixa Lasso llama "mitos de armonía," en el contexto de las luchas de independencia en Colombia y Cuba. Una de las consecuencias de la alianza entre los nacionalistas pardos y los nacionalistas criollos en esos otros escenarios fue la conexión de proyectos abiertamente anti-racistas con proyectos nacionalistas, y la asociación de racismo con colonialismo. Los nacionalistas describían las costumbres locales criollas como progresistas en términos raciales y sociales, mientras que planteaban la injusticia racial en Hispanoamérica como parte de la influencia corrupta o la desafortunada herencia de la administración colonial. Estas políticas estratégicas silenciaban las considerables exclusiones raciales practicadas por la sociedad criolla, y la significativa ambivalencia sobre el tema de la raza que tenían el Estado español y sus defensores. En este sentido, resulta útil leer los escritos de los liberales hispanoamericanos más sobresalientes con una mirada crítica. No obstante, los "mitos de armonía" codificados en dichos textos no eran meras falsedades, ni simples máscaras utilizadas por la elite intelectual para ocultar las realidades de las desigualdades raciales y de clase en la sociedad criolla. Por el contrario, dichos mitos reflejaban la complicada historia de las alianzas y negociaciones entre personas de color, criollos blancos y autoridades españolas acerca de cómo la heterogeneidad racial de las Américas debía determinar las condiciones de la nacionalidad española o la naturaleza de las nuevas repúblicas hispanoamericanas ${ }^{3}$.

Una serie de alianzas y negociaciones similares tuvieron lugar en Puerto Rico durante la segunda mitad del siglo XIX, reuniendo a intelectuales y artesanos de ascendencia africana en el movimiento liberal. Aunque esta alianza liberal nunca se construyó como una rebelión anti-colonialista sostenida, supo tomar prestados muchos de los conceptos desarrollados en las guerras independentistas sudamericanas. Al igual que los liberales pardos en otros lugares, Marín, Figueroa, Marín y sus aliados, presentaron estos alineamientos retóricos como una estrategia para impulsar que los movimientos de reformas coloniales adoptaran ideales anti-racistas. Aunque podemos identificar a Marín, Figueroa y Marín entre los primeros "escritores no-blancos" en Puerto

3. Sobre el radicalismo laboral como respuesta al liberalismo patricio, véase especialmente Gervasio L. García y Angel G. Quintero Rivera, Desafío y solidaridad: Breve historia del movimiento obrero puertorriqueño (Río Piedras, Puerto Rico: Ediciones Huracán, 1982); y Ángel G. Quintero Rivera, Patricios y plebeyos: Burgueses, hacendados, artesanos, obreros (Río Piedras, Puerto Rico: Ediciones Huracán, 1988). Véase también Findlay, Imposing Decency. Para un relato inusual acerca de cómo un escritor negro respondió a un liberal sobre el tema de la raza, véase Miriam Jiménez Román, "Un hombre (negro) del pueblo: Jose Celso Barbosa and the Puerto Rican "Race" Toward Whiteness," Centro, VIII, 1 and 2 (1996). Véase también Marixa Lasso, Myths of Harmony: Race and Republicanism During the Age of Revolution, Colombia 1795-1831 (Pittsburgh: University of Pittsburgh Press, 2007); Ada Ferrer, Insurgent Cuba: Race, Nation, and Revolution, 1868- 1898 (Chapel Hill, NC: University of North Carolina Press, 1999); Alejandro de la Fuente, A Nation for All: Race, Inequality, and Politics in Twentieth-Century Cuba (Chapel Hill, NC: University of North Carolina Press, 2001). 
Rico, generalmente ellos buscaban mostrarse a sí mismos simplemente como liberales e intelectuales, sin ser marcados por el color de la piel o por la clase social. La mayor parte de ellos apoyaron los proyectos liberales de civilización y modernización que racionalizaban una jerarquía imaginaria que distinguía a los hombres urbanos de letras de las masas negras, mulatas y blancas puertorriqueñas. Aun así, sus experiencias transitando el prejuicio racial, la movilidad social y las tensiones implícitas en sus alianzas con gente de ascendencia más privilegiada, claramente informaron su liberalismo político. Dentro de los confines de la esfera urbana pública, buscaron insertar una política radical de igualdad social en los proyectos liberales, argumentando que el abandono de los prejuicios de raza y casta en favor de un sistema de méritos, debería estar en el centro de la reforma colonial. Buscaron consagrar nociones de igualdad social y racial como elementos fundamentales de una identidad "regional" puertorriqueña, y de una sociedad moderna y civilizada. En estos reclamos de igualdad, la masculinidad fue un terreno esencial para medir la injusticia social. Figueroa y los dos Marín argumentaron que los prejuicios de casta y clase, los que atribuían a oficiales españoles conservadores, eran una forma de oscurantismo. Estos vicios coloniales impedían que hombres de mérito fueran hombres plenos, limitando su potencial económico, sus elecciones románticas y sus derechos a responder, de forma varonil, a cualquier afronta verbal o física.

Esta versión radical del "mito de la armonía” puertorriqueña fue crucial para la alianza entre liberales y artesanos en los movimientos abolicionistas y de reforma colonial en Ponce y sus alrededores en la década de 1870 e inicios de la de 1880. Sin embargo, esta alianza comenzó a fragmentarse después del verano de 1887, cuando las autoridades coloniales aplicaron torturas y humillaciones desproporcionadas a los artesanos de color. Arrastrados por estos compontes, Sotero Figueroa y Pachín Marín, ambos claramente identificados con los artesanos a pesar de sus esfuerzos para convertirse en periodistas reconocidos, consideraron la respuesta de los líderes liberales como muy tibia frente a las ofensas españolas. Expresaron una creciente desconfianza hacia los patricios que celebraban la naturaleza pasiva y maleable de los negros puertorriqueños, llamando a una respuesta vigorosa y "masculina" frente a la deshonra que significaba la opresión colonial. Al mismo tiempo, ofrecieron versiones alternativas a importantes historias liberales sobre la paz racial, en la que los negros eran héroes frente a los prejuicios subyacentes, en vez de ser los beneficiarios pasivos de las amistades blancas. En los primeros años de la década de 1890, los dos rompieron con la base institucional del movimiento liberal, el Partido Autonomista, y se mudaron a Nueva York. Allí se unieron al Partido Revolucionario Cubano, a movimientos obreros y a sociedades de color cubanas. También fundaron su propia agrupación política, que buscaba la independencia de Puerto Rico. Figueroa, Pachín Marín y sus aliados en Nueva York, continuaron denunciando el prejuicio social y racial como un vicio colonial y 
siguieron construyendo una visión de un orden social puertorriqueño moderno y republicano en el que, en las palabras de Figueroa, se pudiera "abolir la ley de castas"4.

Este artículo explora lo que los escritores puertorriqueños de ascendencia africana querían expresar al hablar de casta y clase en el contexto de la política liberal y anti-colonialista. Para lograrlo, el mismo considera las formas en que estas ideas se desarollaron dentro de los sistemas de jerarquía y poder que confrontaron estos escritores mientras buscaban reconocimiento profesional, honor y dignidad en las ciudades de Puerto Rico. Entender su especial atención a la masculinidad plena y la reforma colonial, en vez de a la solidaridad racial, requiere ubicar esta ideología dentro de tres contextos coexistentes: un estado colonial ambivalente acerca de la raza, pero dispuesto a utilizar la exclusión racial como herramienta para asegurar su poder político; un movimiento liberal construido sobre las bases de unas frágiles alianzas que incluían a artesanos y hombres de la clase media baja; y un complejo sistema local de aceptación social y exclusión que formó las identidades masculinas públicas y privadas de estos escritores ${ }^{5}$.

\section{COLONIALISMO, CLASE Y RAZA}

Lo que se convirtió en el movimiento liberal organizado en Puerto Rico comenzó en la parte temprana del siglo XIX, con intentos de recolectar y definir una tradición literaria puertorriqueña, separada de la tradición española y no menos valiosa. Los escritores que lideraron esa búsqueda de una tradición literaria criolla eran en su mayoría hijos de los hacendados y oficiales puertorriqueños, que habían completado sus estudios universitarios en Madrid o Barcelona. Por su clase social privilegiada y blancura de piel, porque eran hombres y viajaban constantemente entre la isla y la península, disfrutaban de un estatus comparativamente más alto que la mayoría de los isleños dentro del contexto del régimen colonial. Aproximaban, sin alcanzar, la plena nacio-

4. Jesse Hoffnung-Garskof, "The Migration of Arturo Schomburg: on being Antillano, Negro, and Puerto Rican in New York, 1891-1917," Journal of American Ethnic History. XXI, 1 (2001), y "The world of Arturo Schomburg: Afro-Latinos, African Americans, and the Antillean independence movement, 1879-1914," en Afro-Latinos in the United States: A Reader, ed. Miriam Román y Juan Flores (Durham, NC: Duke University Press, 2009).

5. María del Carmen Baerga-Santini, "Cuando el amor no basta: Matrimonio y racialización en el Puerto Rico del siglo XIX" y "Cuerpos calificados/cuerpos negociados: Sexo, ilegitimidad y racialización en el Puerto Rico decimonónico", Historia y Sociedad, CVI, 16 y 17 (2005-6); Ann Twinam, Public Lives, Private Secrets: Gender, Honor, Sexuality and Illegitimacy in Colonial Spanish America (Stanford: Stanford University Press, 1999) y "The Etiology of Racial Passing: Constructions of Informal and Official "Whiteness" in Colonial Spanish America", en New World Orders, Violence, Sanction, and Authority in the Early Modern Americas, ed. John Smolenski y Thomas J. Humphrey (Philadelphia: University of Pennsylvania Press, 2005). 
nalidad española. En los inicios del siglo, mientras que las tensiones en torno al gobierno local, la soberanía y la representación destruían el vasto Imperio español en las Américas, los criollos puertorriqueños y la ola de exiliados, leales a la corona, del continente decidieron quedarse dentro del sistema español. Muchos soñaron, al igual que sus contrapartes en Cuba, que un estado español reformado apoyaría el crecimiento de la producción de azúcar y café para la exportación. Calcularon que el Estado español apoyaría su posición jerárquica sobre aquellos puertorriqueños que tenían "defectos" sociales, como la falta de legitimidad, alfabetización, pureza de sangre y libertad legal. De hecho, impulsados por el poderío militar español, los hacendados puertorriqueños aún imponían la condición de esclavitud a entre treinta y cuarenta mil personas africanas y afro-puertorriqueñas en la década de 1870, la mayoría agrupada en los enclaves azucareros alrededor de los puertos costeros de Ponce, Mayagüez, Arecibo y Guayama. La ley española también preservaba las distinciones legales entre los criollos ricos y una cantidad mucho mayor de trabajadores rurales libres blancos, no-blancos y negros, llamados jornaleros, y los campesinos, llamados jíbaros, así como de las clases populares urbanas. Los puertorriqueños de una menor "calidad", con menores grados de honor, estaban todos sujetos a restricciones en sus derechos políticos que determinaban con quién podían casarse, qué vestimentas podían usar, cómo podían identificarse a sí mismos, qué profesiones podían ejercer y cómo podían responder a una afrenta verbal y física por parte de alguien de una clase superior. Aun así, la elite criolla tenía un estatus inferior respecto a los peninsulares, españoles nacidos al otro lado del océano. Como respuesta a esto, algunos comenzaron a construir una identidad criolla alternativa y celebratoria de sí misma ${ }^{6}$.

Al igual que en otros contextos coloniales, las expresiones de la identidad criolla se basaron muchas veces en unas nociones interesantes, e incluso subversivas, de casta y raza. Muchas veces, los intelectuales criollos adoptaron la metáfora de la esclavitud, o la imagen del "otro"racializado, para describir su opresión como sujetos coloniales. Esfumaron la frontera simbólica entre ellos como criollos blancos y la población popular mestiza de la isla, usando a los jíbaros y hasta a los morenos como símbolos de la diferencia entre criollos y peninsulares. En el proceso, los intelectuales criollos incorporaron a los hombres de color que consideraban ejemplares para sus esfuerzos de construir una tradición literaria y artística puertorriqueña. El más prominente de ellos era José Campeche, el hijo de un artesano negro libre y de una mujer de las Islas Canarias, que se convirtió en un talentoso pintor del estilo barroco a finales del siglo XVIII. En 1854, el escritor criollo blanco, Alejandro Tapia y Rive-

6. Sobre la evolución de la relación política y económica con España, véase Josep María Fradera, Colonias para después de un imperio (Barcelona: Bellaterra, 2005), 17-76. Véase también Christopher Schmidt-Nowara, Empire and Antislavery: Spain, Cuba, and Puerto Rico, 1833 1874 (Pittsburgh: University of Pittsburgh Press, 1999), 14-51. 
ra, escribió una biografía del pintor, describiéndolo como alguien "de color sonrosado al par que trigueño, laso el cabello y pardos los ojos". Para Tapia y los demás intelecuatales criollos, que buscaban definir su propio estatus como intelectuales nacidos fuera de Europa, Campeche era un símbolo perfecto: un genio nativo de orígenes humildes, desconocido solamente por residir lejos de Madrid o París. Campeche no era completamente blanco, sin embargo, su trabajo estaba a la par del de los grandes maestros de la civilización europea. En la segunda mitad del siglo, Campeche se convirtió en el ícono central del grupo que quería construir una tradición literaria y artística puertorriqueña. En los círculos intelectuales criollos, ser un "admirador de Campeche" era una marca de pensamiento de avanzada y amor hacia la isla ${ }^{7}$.

El puñado de intelectuales criollos de mediados de siglo que tenía los recursos para viajar a través del Atlántico, y podía observar las energías industriales y culturales que tenían lugar en Europa, desarrolló también lo que la historiadora literaria Silvia Álvarez Curbelo llama el "militante deseo y voluntad" de modernidad. Estos intelectuales culpaban a las políticas coloniales españolas y a la monarquía absoluta por lo que entendían como una insoportable inamovilidad y letargo. Sus quejas incluían reclamos sobre los impuestos y tarifas, el poder de la iglesia y las fuerzas armadas, y la falta de promoción de la educación y las ciencias. Pero, para los liberales, la institución de la esclavitud era el impedimento más importante para la modernización y la recuperación moral de Puerto Rico. En la década de 1850, el abogado Segundo Ruis Belvis (hijo de un hacendado blanco) y el doctor Ramón Emeterio Betances (hijo de un hacendado adinerado, con ancestros europeos y africanos) organizaron bautismos en masa para niños nacidos esclavos y promovieron el cimarronaje. Para finales de la década de 1860, un círculo abolicionista mayor y menos militante se formó en la isla y entre puertorriqueños viviendo en España. Ruis Belvis, liderando a un grupo de representantes puertorriqueños en la Junta Informativa de Reformas de Ultramar, un cuerpo creado en Madrid en 1866 para debatir las reformas coloniales luego de finalizada la Guerra Civil en Estados Unidos, luchó, sin mucho éxito, por el fin inmediato de la esclavitud. Los abolicionistas veían la abolición como un imperativo moral, pero también argu-

7. Scarano, "The Jíbaro Masquerade". Manuel Alonso, parte del Grupo Criollo de Barcelona en los 1840s, publicó el texto más famoso del género, El Gíbaro. Véase también el poema de Alonso "Un puertorriqueño" (1844), que describe al puertorriqueño ideal como de "color moreno". Alejandro Tapia y Rivera, "Vida del pintor puertorriqueño José Campeche," El bardo de Guamaní: Ensayos literarios (La Habana, 1862). Manuel Corchado y Juarbe, Obras completas, vol. I (San Juan, Puerto Rico: Editorial ICP, 1975), 45-51. Sotero Figueroa usó el apelativo "admirador de Campeche" cuando enumeró los logros del sacerdote José María Báez, y Figueroa admiró al pintor por razones diferentes. Sotero Figueroa, Ensayo biográfico de los que más han contribuido al progreso de Puerto-Rico (Ponce, Puerto Rico: Establecimiento Tipográfico El Vapor, 1888), y véase Báez sobre Campeche en la Sociedad Económica de Amigos del País, Acta de la junta pública efectuada por la Sociedad Económica De Amigos Del País el 22 de enero de 1863 (Puerto Rico: Imprenta del Boletín Mercantil, 1863). 
mentaron que la transición hacia el trabajo libre ayudaría a sacar a la industria azucarera de Puerto Rico de su deterioro. Razonaron que el trabajo libre era un sistema económico moderno que, a la par de la educación pública, el libre comercio y una mayor autonomía administrativa, traerían el progreso a la isla. En 1868, Betances lideró una rebelión fracasada en Lares, que proponía el fin de la esclavitud y la independencia de España. La mayor parte de los liberales puertorriqueños no se unieron a la rebelión en Lares. En cambio, promovieron reformas negociadas. Y, en todo caso, la mayoría de los puertorriqueños adinerados y educados no eran liberales ${ }^{8}$.

Los abolicionistas, que en gran parte eran los proponentes del "regionalismo" puertorriqueño (el carácter único de la isla como una de las regiones de España), tenían unas nociones complicadas sobre las relaciones raciales. En la década de 1860, oficiales españoles y puertorriqueños conservadores utilizaron los miedos raciales, tal como lo habían hecho durante las guerras de independencia en la década de 1810. Manuel Zeno Correa, el miembro disidente de la delegación puertorriqueña en Madrid en 1866, se unió a los delegados cubanos para advertir que la esclavitud era la base del orden social. De ser los esclavos liberados, se unirían a la clase de la gente no-blanca libre en un "estado de inquietud, de constante libertinaje", amenazando "no solo la riqueza de aquellos pueblos, sino la tranquilidad [y] el bienestar de sus habitantes". Reformistas liberales, como José Pablo Morales, respondieron que Puerto Rico no seguiría el camino de Cuba y Haití, ya que la isla era un lugar sin odios raciales. "Por fortuna", escribió Morales, "como entre nosotros es donde mejor se ha tratado [a] los negros es donde menos odios habrá que extinguir". Para la mayoría de los hombres patricios en el movimiento liberal, esta visión de paz social y armonía racial era igual a sus identidades literarias adoptadas de jíbaros o morenos. Esa imagen se apoyaba sobre un proyecto que no buscaba un igualitarismo radical, sino más bien una incorporación ordenada de los jornaleros negros (trabajadores semi-libres) y de los jíbaros casi blancos a un nuevo régimen de trabajo libre bajo la dirección de los criollos blancos ${ }^{10}$. La noción de armonía racial criolla, en oposición al racismo español, no solamente omitía el rol de los criollos en el establecimiento y la

8. Álvarez Curbelo, Un país del porvenir: El afán de la modernidad en Puerto Rico, siglo XIX (San Juan, Puerto Rico: Ediciones Callejón, 2001), 52, 113-31. Véase también Schmidt-Nowara, Empire and Antislavery, 100-25; Olga Jiménez de Wadenheim, El Grito De Lares sus causas y sus hombres, 5ta edición (Río Piedras, Puerto Rico: Ediciones Huracán, 2004); and Félix Ojeda Reyes, El desterrado de París: Biografía del Doctor Ramón Emeterio Betances, 1827-1898 (San Juan, Puerto Rico: Ediciones Puerto, 2001), 40-56.

9. Zeno Correa en Información sobre reformas en Cuba y Puerto Rico celebrada en Madrid en 1866 y 67 (Impr. de Hallet y Breen, 1877), 52; también citado en Álvarez Curbelo, Un país del porvenir, 128-9.

10. José Pablo Morales, Misceláneas (San Juan, Puerto Rico,1895; reimpreso en la Colección Alice B. Gould); Lasso, Myths of Harmony, 34-67. 
defensa de las jerarquías raciales, sino que también exageraba las diferencias con el Estado español (e incluso con los puertorriqueños conservadores). Representantes de la corona, tanto peninsulares como puertorriqueños, desplegaron algunas veces diferencias raciales o la amenaza de la división racial para ampliar sus objetivos políticos. Sin embargo, España no tenía una política estricta o consistente de clasificación racial y exclusión ${ }^{11}$.

Quizás más importante, al igual que en las revoluciones en Colombia y Venezuela, que tuvieron lugar medio siglo antes, estas nociones de paz social no fueron creadas solamente por la elite criolla, sino que se desarrollaron dentro del contexto de las alianzas y negociaciones con los puertorriqueños de un estatus social más bajo. Un grupo de intelectuales liberales con "defectos" sociales que habían logrado un nivel de movilidad social ascendente considerable, participaban en la construcción de las ideas liberales sobre clase, legitimidad y raza. Por ejemplo, en Ponce, el líder del movimiento liberal era Román Baldorioty de Castro. Nacido en 1822, Baldorioty era un "hijo natural", y posiblemente un mulato ${ }^{12}$. Recibió su educación básica en San Juan de parte de Rafael Cordero. Cordero era un cigarrero negro, que aprendió por su cuenta a leer y escribir. Fundó y operó la Escuela de Párvulos, donde educó a los niños pobres junto a muchos hijos de la elite de San Juan. A diferencia de la mayoría de los estudiantes plebeyos de Cordero, que tenían que trabajar para subsistir después de terminar la escuela primaria, Baldorioty estudió en la escuela secundaria fundada por el sacerdote Don Rufo Manuel Fernández. Instada por Don Rufo, la Sociedad Económica de Amigos del País escogió a Baldorioty y a su compañero de clases, José Julián Acosta, el hijo legítimo pero indigente de un escriba blanco, como los beneficiarios de una beca universitaria para estudiar en España. Baldorioty y Acosta se mezclaron con pensadores liberales en Madrid, y se convirtieron en líderes propulsores de las reformas coloniales liberales y el abolicionismo en Puerto Rico y España. Acosta sirvió junto a Ruis Belvis en la comisión puertorriqueña de la Junta Informativa en Madrid en 1866, apoyando un llamado a la abolición inmediata. Baldorioty trabajó como corresponsal para la comisión puertorriqueña en la Exposición Mundial de París en 1867. Ambos parecen haber sido también patrocinadores de otros hombres de esta-

11. Fradera, Colonias, 77-103. Véase también Josep Maria Fradera, Gobernar colonias (Barcelona: Península, 1999), 51-69; Lasso, 16-33.

12. Luis M. Díaz Soler, Historia de la esclavitud negra en Puerto Rico (Río Piedras, Puerto Rico: Editorial Universitaria, Universidad de Puerto Rico, 1981), 299, 304-305. Hijos naturales eran aquellos cuyos padres no se encontraban casados pero que cumplían con los requisitos legales para poder casarse. No estaban ya casados con otras personas (lo que hubiera hecho a sus hijos adulterinos) ni eran sacerdotes o monjas (lo que hubiera hecho a los hijos sacrílegos). Después de los expósitos, que eran los que no tenían un parentesco conocido o documentado, los hijos naturales tendían a ser la categoría más favorecida entre los hijos ilegítimos. Podían convertirse en legítimos luego de que sus padres contrajeran nupcias, y muchas veces se entendía que habían sido concebidos bajo circunstancias excusables. Esto no eliminaba el elemento de incertidumbre racial que compartían con niños no reconocidos por uno o ambos padres. 
tus inferior dentro del movimiento. Acosta empleó a Pansacio Sancerrit como operador de su casa editorial y su periódico en San Juan. Sotero Figueroa escribiría luego, nacido "entre los desheredados de la tierra", Sancerrit comenzó a trabajar como guardia en una casa de comercio a los catorce años. Aprendió por sí mismo humanidades, matemáticas e idiomas. Eventualmente se convirtió en maestro de escuela, periodista y un prominente intelectual liberal ${ }^{13}$.

Igualmente, el periodista y maestro escolar Ramón Marín se convirtió en un aliado crucial de Baldorioty, quien publicaba su periódico en la imprenta de Marín en Ponce. Marín era el hijo natural de Rosa Solá, identificada en su partida de bautismo como una "esclava de Vicente Marín". Vicente, un inmigrante italiano soltero con una fortuna modesta, le dio su libertad a Ramón (y eventualmente también a Rosa) y lo apoyó en sus estudios secundarios. Cuando Ramón alcanzó los dieciocho años, Vicente informó a los funcionarios coloniales de hacienda que Rosa Solá, una mulata libre y soltera, vivía con él como sirvienta, con sus hijos mulatos, Ramón y seis hermanos y hermanas. Vicente jamás reconoció oficialmente como sus hijos a Ramón ni a sus hermanos, en el contexto eclesiástico o civil. Sin embargo, Ramón publicó un poema recordando a su padre después de su muerte, que sugería una relación cercana entre ambos. Ramón recordó que era su padre "El que acallaba mi aflicción sentida / Con tierno abrazo y repetido beso". Es posible que este recuerdo haya sido retocado para encajar con la imagen posterior de Ramón como un hombre de letras respetable, pero igualmente es posible que la relación afectiva aquí descrita haya sido real. Documentos oficiales y públicos, como era común en este tipo de situación, preservaban la apariencia de respetabilidad de Vicente, degradando a su familia al estatus público de sirvientes. Sin embargo, no hubiera sido inusual que Rosa, Ramón y sus demás hermanos simultáneamente mantuvieran un estatus privado como miembros queridos de la familia. Parece probable que la familia ilegítima de Vicente también haya gozado de un reconocimiento público informal, ampliamente reconocido y aceptado por su círculo íntimo y también por la sociedad de Arecibo ${ }^{14}$.

13. Para los archivos del bautismo de Acosta y Baldorioty, véase Martín Gaudier, Genealogías puertorriqueñas: partidas de bautismos y biografías (Puerto Rico [s.n.], 1963). Gaudier no especifica si las partidas de bautismo fueron publicadas en el "Libro de Pardos", pero la madre de Baldorioty es identificada como una "persona blanca". La raza de su padre, que fue añadida al documento quince años después cuando reconoció su paternidad, no aparece, y tampoco aparece con el título de "don”. La mayoría de los biógrafos no mencionan su legitimidad o su raza. Isabel Zenón Cruz argumenta que Baldorioty era considerado mulato por sus contemporáneos, pero tiende a ser blanqueado en los relatos historiográficos. Véase César Ayala y Rafael Bernabe, Puerto Rico in the American Century (Chapel Hill, NC: University of North Carolina Press, 2007), 256. La historia de su educación ha sido relatada en muchas instancias - ver, por ejemplo, José A. Gautier Dapena, Baldorioty, apóstol (San Juan, Puerto Rico: Editorial ICP, 1970), 14-18. Sobre la escritura de Baldorioty, ver Álvarez Curbelo, El país del porvenir, 167. Sobre Sancerrit, ver Figueroa, “Pascacio Sancerrit, 1833-1876”, en Ensayo biográfico.

14. Catedral San Felipe Apóstol, Arecibo, Puerto Rico, "Libro de bautismos 3, folio 99", 
De hecho, poco después de que apareció en el cadastro como hijo de la empleada doméstica de Vicente, Ramón pudo, incrementalmente, conducir sus asuntos públicos como si fuera el hijo reconocido de Vicente y como si fuera un hombre sin "defectos" sociales, un hombre de honor. Empezó a aparecer en documentos públicos con el apellido Marín. Se mudó a Cabo Rojo para ocupar un puesto como maestro de escuela. Se casó con Amalia Castillo, la hija legítima de una pareja blanca de Ponce. En resumidas cuentas, no sufrió los impedimentos legales que oficialmente restringían la movilidad social de aquellos nacidos en la ilegitimidad o sin pureza de sangre, impedimentos que permanecían en las leyes de Puerto Rico hasta las décadas de 1870 y 1880 . Técnicamente, Ramón no debería haber podido usar el título honorífico de don, debería haber sido excluido de ciertas profesiones, incluyendo la de maestro de escuela, y habérsele prohibido ocupar cargos públicos, incluyendo el puesto de maestro. Los padres de Amalia Castillo pudieron haberlo demandado para impedir que se casara con ella, basados en el hecho de que su hija era de una calidad significativamente más alta. Sin embargo, al igual que Baldorioty y Sancerrit, esas negociaciones exitosas de Ramón Marín no eran tan extraordinarias. El Estado español, aunque comprometido generalmente con el principio jerárquico, no estaba particularmente preocupado con vigilar estas fronteras sociales específicas. El Estado no producía ni recolectaba información sobre la composición racial de sus súbditos, dejando ese trabajo a los registros de las parroquias y a las costumbres y usos locales. Cuando aparecían conflictos, por ejemplo, si alguna familia objetaba un matrimonio bajo el principio de la desigualdad de condición entre los novios, el Estado examinaba los archivos de bautismo. Sin embargo, muchas veces dichos registros se construían de una forma intencionalmente vaga con relación al estatus de nacimiento. Por eso, el Estado entrevistaba también a vecinos con honor incuestionable. De manera interesante, lo que no hacía era examinar los cuerpos de aquellos acusados de tener orígenes africanos. La raza no era una categoría que se podía decidir de forma definitiva al examinar documentos o el fenotipo. Era, mayormente, una cuestión de reputación, o fama, lo que significaba que la sociedad local tenía considerable libertad de acción cuando decidía pasar por alto los asuntos de nacimiento y color ${ }^{15}$.

reimpreso en Ramón Marín, Obras completas, ed. Socorro Girón (Ponce, Puerto Rico, 1989), 9. Véase también la biografía introductoria de Socorro Girón en Ramón Marín, Las fiestas populares de Ponce (San Juan, Puerto Rico: Editorial Universidad de Puerto Rico, 1994), 11-56. Sobre la relación con su padre, ver Ramón Marín, “Tres años después, ante los restos de mi padre”, en Marín, Obras completas, 189-90. Para los récords de impuestos, ver Archivo General de Puerto Rico (AGPR), Fondo Municipal de Arecibo. Caja 68. Secretaría. Censos. Padrón de Almas y Riqueza. Bo. Rosario [1847].

15. Baerga-Santini, "Cuando el amor no basta" y "Cuerpos calificados". Ver también Twinam, Public Lives, Private Secrets y "The Etiology of Racial Passing;" Verena Martínez-Alier, Marriage, Class and Colour in 19th Century Cuba (Ann Arbor: The University of Michigan Press, 
Las reputaciones podían construirse a través del comportamiento público impecable o incluso a través de un matrimonio honorable con una familia de alta posición. Bajo la lógica de que el comportamiento deshonroso, especialmente la conducta sexual inapropiada, era un marcador inevitable de impureza de sangre, el comportamiento honorable podía ser evidencia de pureza de sangre, o, al menos, de ser casi blanco. De acuerdo con la lógica de los investigadores, una familia de alta posición no consentiría un matrimonio con alguien de menor calidad, de modo que en años subsiguientes, ese matrimonio serviría como una evidencia generalmente aceptada de un nacimiento honorable. A través de su educación, su comportamiento público, la confabulación de conexiones familiares y sociales (incluyendo, quizás, el reconocimiento informal y el apoyo financiero de su padre), Ramón Marín construyó la identidad pública de un hombre honorable, a pesar de sus defectos como hijo ilegítimo, su ascendencia africana y su conexión familiar a la experiencia de la esclavitud. Es esto último lo que hace el caso de Marín diferente a los de Baldorioty y Sancerrit. Aunque las realidades privadas de su nacimiento natural e incluso su procedencia racial mixta fueran ampliamente conocidas y toleradas, es probable que el ocultar la esclavitud de su madre requirió de algún esfuerzo ${ }^{16}$.

Antes de cumplir sus treinta años, Marín puso en riesgo su ascenso social al comenzar su carrera como escritor liberal, creando lazos con Acosta y Baldorioty. En 1865, las autoridades amenazaron con cerrar una escuela que administraba en Yabucoa, acusándolo de haber reemplazado un mapa de España, en la pared de su salón de clases, con la imagen de la cabeza de un burro. A pesar de la acusación de que era un filibustero, o separatista, continuó dando clases y añadió clases nocturnas para adultos. En 1869 compitió en una convocatoria abierta para un puesto como maestro de escuela secundaria en Ponce. Ganó la posición después de una "competencia rigurosa", pero luego escribió que el puesto le fue negado "por motivos injustificables, de los que jamás se me dio conocimiento" 17 . Probablemente, la razón fue su reputación de que difundía ideas anti-españolas en el salón de clases. Sin embargo, sus conexiones con el liberalismo no eran simplemente una amenaza a su movilidad social. La oposición a las leyes que discriminaban por raza o legitimidad y el ejemplo de hombres que avanzaban socialmente a través de su compromiso con la educación

1989); y Susan Socolow, "Acceptable Partners: Marriage Choice in Colonial Argentina (17781810)," en Sexuality and Marriage in Colonial Latin America, ed. Asunción Lavrin (Lincoln: University of Nebraska Press,1989), 209-51.

16. Baerga-Santini, "Cuando el amor no basta."

17. Sobre la sugerencia de que Marín fue apoyado por su padre, véase Ángel G. Quintero Rivera, "The Somatology of Manners: Class, Race and Gender in the History of Dance Dtiquette in the Hispanic Caribbean," en Ethnicity in the Caribbean, ed. Gert Oostindie (London: Macmillan Education, 1996), 174. Sobre su certificación como maestro, véase "Profesor D. Ramón Marín por no concederle el Gobernador Sanz la escuela principal de Ponce," 23 de abril de 1883, ed. Cayetano Coll y Toste, Boletín histórico de Puerto Rico, vol. 5 (New York, 1968), 237-8. 
eran importantes para la ideología liberal sobre raza y clase. En 1867, los comisionados puertorriqueños en Madrid argumentaron en contra de cualquier restricción legal a las personas libres de color, incluyendo los esclavos recién liberados. Argumentaban que dichas leyes solo fomentarían divisiones y odios entre la población puertorriqueña y eran contrarias a la identidad regional de la isla. El escritor liberal, José Pablo Morales, sostuvo que los criollos debían asegurarse, cuando reclamaban una ciudadanía más completa para ellos mismos, de incluir a hombres de color bien posicionados. Esto, argumentó, solamente confirmaría en la ley algo que ya era común en la costumbre de Puerto Rico. Hacia finales de la década de 1860, Morales escribía: “QQué puerta hay vedada para un mulato en Puerto Rico con inteligencia y dinero que no lo esté también para el blanco criollo?"18

Hombres como Baldorioty, Marín y Sancerrit quizás entendieron un poco mejor que Morales las dificultades de negociar su movilidad social dentro de la sociedad criolla; entendieron mejor que él que esas puertas, cuando estaban abiertas, solo lo estaban de manera parcial. Aun así, todos estaban completamente de acuerdo en que tanto los privilegios sociales como los legales, basados en la clase y raza, debían ser eliminados. En vista de que su ascenso social se debía a su educación, y de que frecuentemente se ganaban la vida trabajando como maestros, consideraban que la riqueza económica era un fundamento mucho menos importante que la inteligencia y el aprendizaje para la igualdad social. Aunque no cuestionaron la noción prevaleciente de que la clase trabajadora puertorriqueña se encontraba degradada y era inmoral, creían que los hombres de todos los estratos sociales podrían ser perfeccionados a través de la educación. Citando a John Stuart Mill y los escritos de republicanos catalanes, argumentaban que leyes de trabajo justas, la educación pública y las organizaciones de trabajadores, mejorarían las condiciones de vida para los trabajadores libres, levantarían su nivel moral e intelectual y asegurarían tanto la armonía social como el progreso económico ${ }^{19}$. El enfoque en la educación secular, la regeneración individual y colectiva, así como la armonía social reflejan también la influencia de toda una serie de corrientes intelectuales heterodoxas que venían desarrollándose en España y sus colonias durante ese periodo, que incluían la masonería, el krausismo y el espiritismo ${ }^{20}$.

Teóricamente, estos pensadores liberales soñaban que estas reformas se aplicarían a la gran mayoría de los trabajadores puertorriqueños, que vivían en los campos o en las afueras de la ciudad, los jíbaros, jornaleros y esclavos

18. Información sobre reformas, 123-8; Morales, Misceláneas, 198-9.

19. Sobre el pensamiento de los liberales españoles, véase Schimdt-Nowara, Empire and Antislavery, 74-88. Sobre el pensamiento de Baldorioty, Marín, Sancerrit y otros, véase Lidio Cruz Monclova, Historia de Puerto Rico (Siglo XIX), Vol. II, (1875-1885) (Río Piedras, Puerto Rico: Editorial Universidad de Puerto Rico, 1957), 930-40.

20. Lisa Abend, "Specters of the Secular: Spiritism in Nineteenth-Century Spain," European History Quarterly XXXIV, no. 3 (2004), 507-34. 
libertos. Los comisionados liberales en Madrid argumentaron que la igualdad y la educación eran mejores garantías para mantener la paz social que las leyes contra la vagancia. Pero esperaban que el rol de educar y civilizar a las masas rurales recayera en esa clase "honrada y laboriosa" de gente de color libre ${ }^{21}$. Aunque la propuesta de abolición de los comisionados fue infructuosa, en la isla los liberales citadinos lograron un acercamiento con los artesanos urbanos. Los artesanos era el grupo de trabajadores que tenían más accesible, que mejor representaba sus ideales de una clase trabajadora mejorable y digna, y que en su mayoría coincidía con esa clase "honrada y laboriosa" de la población libre de color a la que imaginaban como sus aliados en el proyecto más grande para regenerar los trabajadores puertorriqueños. Hacia finales de la década de 1860 y principios de 1870, los liberales apoyaron la organización de clubes y cooperativas de artesanos. Mientras predicaban la decencia, el ahorro, la ayuda mutua y la autoeducación para los trabajadores, presentaban estos clubes ante el público patricio como la evidencia de la capacidad de la población no-blanca para ser miembros honorables y productivos de la sociedad urbana. A pesar de que los pensadores liberales y los artesanos mismos usualmente se referían a estos clubes en términos de la profesión de sus miembros, como casinos de artesanos, es importante destacar que en Puerto Rico la gran mayoría de los artesanos eran hombres de color libres. De hecho, en la década de 1880, un español que visitó estos clubes los describió como meros casinos de negros. Podemos ver entonces que la categoría ocupacional de "artesano" conllevaba significados tanto de raza como de clase. Teniendo eso en cuenta, los artesanos (y los que los apoyaban) fueron cuidadosos a la hora de distinguir entre artesanos y otros tipos de trabajadores que también habían sido racializados: los jornaleros, los esclavos o los vagabundos. En 1875, Marín escribió que "esta clase, digna de toda consideración y respeto, [que] tiene sus círculos honestos, decentes y cultos" no frecuentaba los bailes populares "como algunos creen". A semejantes bailes, que para él eran escandalosos, "s[o]lo concurren la parte más abyecta de la sociedad"22.

$\mathrm{Al}$ igual que los puertorriqueños que buscaban un símbolo de la creatividad criolla y lo encontraron en el pintor Campeche, los liberales que soñaban con educar y elevar a la clase trabajadora urbana (y en reclutarlos para el proyecto de civilizar a las masas rurales) comenzaron a venerar a la figura de Rafael Cordero, un tabaquero y maestro de escuela negro. En 1887, un periódico abolicionista en España publicó una reseña biográfica de Cordero. Era "pasmoso", el escritor opinó, que "un pobre negro, abrumado por las dificultades que engendra la pobreza y marcado con el sello fatal que distingue a

21. Información sobre reformas, 262.

22. Gervacio García, "El casino de artesanos: Del rigodón a la huelga," en García y Quintero Rivera, Desafío y solidaridad. Véase también Marín, Las fiestas populares, 101-5, 11-13; y F. Peris Menchieta, De Madrid a Panamá: Gigo, Tug, Tenerife, Puerto Rico, Cuba (Madrid, 1886). 
su desgraciada clase, haya podido ofrecer un espectáculo tan sorprendente de virtud, abnegación y patriotismo". En 1868, más de 2000 personas asistieron al funeral de Cordero en San Juan, presidido por una serie de oradores liberales. Cordero no era solamente un ejemplo de un artesano que había superado su estatus social y se había convertido en un héroe criollo, sino que era también un ejemplo de la moralidad de la clase trabajadora negra, y un maestro para la población pobre urbana. La conmemoración de su escuela, en el cual héroes liberales como Alejandro Tapia y Rivera se habían formado junto a los hijos de artesanos negros, sirvió como modelo para un movimiento que buscaba incorporar tanto a la elite blanca y los profesionales y escritores no-blancos, como a los artesanos negros. Los liberales resignificaron el salón de clases de Cordero como la representación de la armonía de clase y raza, una idea expresada por los krausistas en las universidades y sitios de reunión en España, y que para los liberales ya era una realidad social en Puerto Rico.

Los acercamientos de los liberales puertorriqueños a los trabajadores urbanos alfabetizados, muchos de los cuales no eran blancos, se convirtieron en una parte importante de la estrategia política después de 1868, cuando los liberales españoles derrocaron a la monarquía en España. En 1869, Baldorioty y Sancerrit aprovecharon la oportunidad para ser parte de la delegación para la asamblea constituyente en Madrid. En 1870, los liberales puertorriqueños prevalecieron en sus reclamos ante el Ministerio de Ultramar para que suspendieran la práctica de investigar (aunque fuera inconsistentemente) la "pureza de sangre" de los candidatos a puestos públicos. En 1871, las Cortes expandieron el sufragio a todos los hombres alfabetizados en Puerto Rico, sin distinción de raza o clase. Esto reforzó la reciente alianza entre los liberales y los relativamente pocos trabajadores alfabetizados en Puerto Rico, la mayoría de los cuales eran artesanos urbanos. Rápidamente, los liberales llevaron su mensaje a los nuevos votantes. Tiempo después, Figueroa escribió que Sancerrit no descansó en ese esfuerzo: Le "vimos no s[o]lo aconsejar [a] los tardos y perezosos para que se apresurasen [a] reclamar el derecho electoral, sino en algunas ocasiones llenar las formalidades necesarias [a] aquellos que aún no estaban habituados á las prácticas de sistma representativo". En 1873, con el consentimiento reacio de los hacendados en Puerto Rico, y a instancias de los representantes puertorriqueños electos bajo las nuevas leyes de sufragio, los liberales en las Cortes aprobaron la legislación para acabar con la esclavitud en Puerto Rico ${ }^{23}$.

Siempre atentos a los simbolismos, en marzo de 1873, los abolicionistas de San Juan organizaron un jubileo para celebrar el fin de la esclavitud. Reafirmando su mensaje de paz social, como parte de la gran procesión, un grupo de libertos marcharon en silencio detrás de los abolicionistas victoriosos, lide-

23. El artículo en Las Antillas es citado por Figueroa, Ensayo biográfico, 183. Él es también la fuente del funeral de Cordero. Véase también Cruz Monclova, Historia de Puerto Rico (Siglo XIX), 472-4; y Schmidt-Nowara, Empire and Antislavery, 141-57. 
rados por Acosta. El periodista Félix Padial, quien pertenecía a una familia de la elite criolla, se paseó abrazando a la gente negra y besando a los niños, gritando "Y a quien diga que esta grandeza no ha sido verdad, que estos esclavos no han entrado en la libertad sin odio, le diré que miente!". Los abolicionistas reafirmaron también la idea de que estaban extendiendo sus brazos a los artesanos y negros que ellos veían como decentes y cultos. En las festividades de la noche, otro de los estudiantes plebeyos de Cordero, un tipógrafo llamado Sotero Figueroa, hizo su primera aparición pública como miembro del círculo liberal. El Círculo Literario y Artístico escogió al joven de veintidós años para representar el grupo en su presentación formal al primer gobernador liberal de Puerto Rico, Rafael Primo de Rivera. Nacido en San Juan en 1853, en el seno de una familia de pardos libres, Figueroa estudió en la escuela de Cordero. Incapaz de pagar sus estudios secundarios, se convirtió en aprendiz de tipógrafo en la imprenta de José Julián Acosta. Allí encontró un mentor en la figura del administrador de la imprenta, Sancerrit. Años después, Figueroa recordó que Sancerrit "fomentó en nosotros las aficiones literarias". El regente de la imprenta de Acosta "nos indicó los autores que debíamos consultar para que formásemos buen gusto; y él por último, con dócil complacencia, examinó más de una mezquina producción nuestra, señalando y aplaudiendo, sin duda para estimularnos, lo que juzgaba de algún mérito”. Cuando llegó la abolición, aparentemente ya Sancerrit y Acosta habían introducido a Figueroa, el ejemplar artesano intelectual, a los círculos literarios liberales. Aunque Figueroa no había sido un esclavo, seguramente los abolicionistas en asamblea valoraron el simbolismo de tener a un hombre no-blanco ofreciendo su gratitud por el fin de la esclavitud. Pero para los liberales sociales que argumentaban a favor del proyecto de mejoramiento de los trabajadores y hombres no-blancos, y para los que querían reclutar a los nuevos votantes de la clase trabajadora urbana a ser parte de la coalición liberal, el reconocimiento público de los talentos literarios de un joven tipógrafo de ascendencia africana también era muy importante ${ }^{24}$.

El interludio liberal tuvo un final abrupto a finales de 1874, con la restauración de la monarquía en Madrid, y la vuelta de los políticos conservadores a cargo del Ministerio de Ultramar. Al igual que en tiempos anteriores, el Estado colonial se aprovechó de las cuestiones de casta y clase para minar estratégicamente la coalición liberal. En concierto con los criollos conservadores, España impuso grandes restricciones (los votantes tendrían que pagar un mínimo de impuestos, con la excepción de los profesionales, los miembros de las fuerzas armadas y los burócratas coloniales) para reducir el electorado en Puerto Rico

24. Sobre el discurso de Figueroa, véase "El 22 de Marzo de 1873, La abolición de la esclavitud en Puerto Rico," en Patria, 1 de abril 1893. Para su biografía temprana, véase Josefina Toledo, Sotero Figueroa, editor de Patria: Apuntes para una biografía (La Habana: Editorial Letras Cubanas, 1985). Sobre su trabajo en la imprenta de Acosta y la relación con Sancerrit, véase "Pascasio Sancerrit," en Figueroa, Ensayo biográfico. 
de cerca de 20000 en 1871 a cerca de 3000 para 1878. Estas restricciones en el sufragio afectaron desproporcionadamente a los artesanos urbanos (la mayoría de ellos pardos) que acababan de ganar el derecho al voto. Años después, Figueroa escribió que los conservadores se apoyaron en la "teoría de las castas" para asegurar sus victorias en la década de 1870. Sin embargo, la movida fue mayormente estratégica. Los conservadores no desplegaron un discurso de deficiencia racial para apoyar los cambios a la ley. En 1880, el líder del Partido Conservador, Pablo Ubarri, explicó que las restricciones al sufragio eran necesarias para asegurar la victoria del Partido Incondicionalmente Español ${ }^{25}$. A su vez, la acusación de la amenaza de una rebelión racial era una herramienta útil para el aparato estatal que quería desacreditar el movimiento reformista. En 1875, el Gobernador General Sanz pidió al Ministerio de Ultramar que impidiera la migración de trabajadores de las islas de Santo Tomás y Santa Cruz, porque eran "de raza de color, instintivamente enemiga de la blanca". Su posible unión con criollos de dudosa lealtad a España hacía a estos trabajadores negros propensos a "formar el núcleo de base de una insurrección separatista". Eventualmente, podrían querer crear una república independiente negra como la de Haití. Esta era la misma lógica-que representaba al movimiento reformista y al separatismo como amenazas raciales-que los conservadores puertorriqueños usaron para oponerse a la abolición en la década de 1860, y que las autoridades españolas usaron como arma de propaganda en contra de los insurgentes en Cuba en la década de $1870^{26}$.

Durante la Restauración, el Estado también tomó medidas contra los periódicos y las organizaciones liberales. Baldorioty escapó a Santo Domingo. A su regreso, las autoridades coloniales le prohibieron ejercer como maestro. Luego, se mudó a Ponce, donde comenzó a publicar el periódico El Derecho. Aunque la mayoría de los liberales de aquel momento (incluido Acosta) proponían la "asimilación" de los puertorriqueños para ser ciudadanos españoles plenos, Baldorioty argumentaba que la naturaleza distintiva de la sociedad puertoriqueña favorecía a la isla para pedir por su autonomía, basándose en el modelo de relación que Canadá tenía con Gran Bretaña. También abogó a favor del sufragio universal masculino, las libertades civiles y el republicanismo. Ramón Marín también se mudó a Ponce, luego de que las autoridades cerraran su escuela en Yauco. Compró una imprenta en Ponce, el Establecimiento Tipográfico "El Vapor", y comenzó a publicar su propio periódico semanal, El Avisador, y luego también La Crónica. Marín también abogó a favor de la autonomía

25. Pablo Ubarri, "Carta oponiéndose a la extensión del sufragio", reimpreso en Coll y Toste, Boletín histórico de Puerto Rico, 229.

26. Cita de Sanz en Cruz Monclova, Historia de Puerto Rico (Siglo XIX), 418. Sobre la "teoría de las castas", véase Sotero Figueroa, Antonio Vélez Alvarado y F. Gonzalo Marín, "Al pueblo puertorriqueño - Club Borinquen," en Boletín histórico de Puerto Rico, ed. Cayetano Coll y Toste (New York, 1920), 72. 
y, en 1880, le cedió la dirección de La Crónica a Baldorioty. Figueroa también se mudó a Ponce en los años de 1870, consiguiendo trabajo como tipógrafo en la imprenta de Ramón Marín. Entusiasmado con pasar de ser tipógrafo a ser editor y autor, en 1880 fundó su propia imprenta en Ponce y comenzó a publicar su propio periódico, El Eco de Ponce. También se convirtió en auspiciador de un programa social progresista a favor de la autonomía. Cuando su imprenta y periódico fracasaron, regresó a la imprenta de Marín, donde se convirtió, como diría después José Martí, en el "compañero privilegiado" de Baldorioty de Castro. Figueroa fue uno de los escritores que contribuyó con La Crónica y el periódico de Marín, El Pueblo, y sustituyó a Baldorioty y a Marín como redactor principal cuando estaban ausentes. En 1881, fue encarcelado por un corto periodo por abogar por la autonomía en un artículo publicado en el periódico La Civilización. Figueroa parece haber sido uno de los intermediarios principales entre los escritores liberales y los grupos emergentes de artesanos. En 1883, fue el orador principal del evento inaugural del Centro de Recreo e Instrucción para Artesanos en Juana Díaz. El alcalde de Juana Díaz, Policarpio Echevarría llegó con un grupo de "voluntarios" conservadores, que obligaron a Figueroa a bajar del estrado y disolvieron el grupo de trabajadores presentes en el evento. Sin embargo, no se limitó a ser el enlace con los grupos de trabajadores. En 1886, “Don Sotero Figueroa” participó en una comisión convocada en Aibonito, por miembros conservadores y liberales de la elite comerciante y hacendada, para estudiar y proponer reformas económicas para la isla. También estuvo presente durante la asamblea en la cual se fundó el Partido Autonomista en 1887, como representante del periódico de Marín El Pueblo, y como el delegado electo de los pueblos de Moca y Bayamón ${ }^{27}$.

Mientras el liderazgo de Baldorioty revitalizaba el movimiento liberal en la década de 1880, otro tipógrafo y escritor, Francisco Gonzalo Marín, se unió a Figueroa en Ponce. Nacido en la década de 1860, "Pachín” era considerablemente más joven que Figueroa, quien aparentemente lo habría tratado como a un hijo. En realidad era el hijo de Santiago Marín (el hermano menor de Ramón Marín). A diferencia de Ramón, quien se había casado con una mujer

27. Sobre la represión, las mudanzas de Baldorioty y las restricciones del sufragio durante este periodo, véase Cruz Monclova, Historia de Puerto Rico (Siglo XIX), 418-19, 72-4, 532. Sobre Marín, véase Marín, Las fiestas populares, 19. Un solo ejemplar de El Eco de Ponce (12 de julio de 1880) queda preservado en micropelícula en las colecciones de la Universidad de Puerto Rico. La cita de Martí aparece en la reseña biográfica sobre Figueroa que fue publicada originalmente en La Igualdad, el periódico publicado por Juan Gualberto Gómez en La Habana. Reimpreso en Félix Ojeda Reyes, ed., Peregrinos de la libertad, documentos y fotos de exilados puertorriqueños del siglo XIX localizados en los archivos y bibliotecas de Cuba (Río Piedras, Puerto Rico: Instituto de Estudios del Caribe, 1992), 168-70. Sobre el arresto de Figueroa y los eventos en Juana Díaz, véase Cruz Monclova, Historia de Puerto Rico (Siglo XIX), 551; Lidio Cruz Monclova, Historia de Puerto Rico (Siglo XIX) vol. III (1885-1898) (Río Piedras, Puerto Rico: Editorial Universidad de Puerto Rico, 1962), 43. Acta de la Asamblea Constituyente del Partido Autonomista Puertorriqueño (San Juan, 1992). 
blanca, Santiago se casó con la hija de un inglés y una mujer africana. Mientras que en Ponce sus primos se acercaban cada vez más a ser vistos como blancos, Pachín creció como un artesano mulato en Arecibo. Después de terminar su educación primaria, se convirtió en aprendiz de tipógrafo. Era un destacado bohemio, que de adolescente compuso canciones y actuó como músico en fiestas en las plazas públicas de la ciudad. Además, empezó su carrera de escritor enviando poemas y artículos al periódico de Ramón en Ponce y comenzó a viajar a dicha ciudad para participar en organizaciones políticas liberales. En 1887, el establecimiento El Vapor publicó su primera colección de poesía, titulada Mi óbolo, dedicada a los miembros de la Asamblea Autonomista. Poco tiempo después comenzó a publicar su propio periódico, El Postillón $n^{28}$. Como intelectuales pardos de la clase artesana, Figueroa y Pachín Marín formaron parte de un grupo mayor de profesionales, que incluía periodistas y maestros con antepasados artesanos y ascendencia africana, que aparecieron en las ciudades puertorriqueñas durante la década de $1880^{29}$. Hombres destacados a pesar de los "defectos" de nacimiento, como Baldorioty y R. Marín, intelectuales, profesionales y escritores de la clase artesanal con ascendencia africana, junto a unos pocos aristócratas y un número mayor de artesanos, se convirtieron en la facción radical del movimiento liberal en Puerto Rico durante este periodo. Favorecían el sufragio universal, la abolición de los prejuicios de clase o casta, la obtención de la ciudadanía española, la libertad de prensa y de expresión, y la autonomía, basados en el modelo de la Canadá británica ${ }^{30}$.

28. Sobre la biografía de Marín, véase Cayetano Coll y Toste, "Francisco Gonzalo Marín," Boletín histórico de Puerto Rico, vol. 12 (New York, 1926); José de Jesús Esteves, Estudio biográfico del poeta arecibeño F. Gonzalo Marín (Manatí, Puerto Rico, 1913); y F. G. Marín,"Mi hermano ha muerto," Patria, 13 de junio de 1896. Véase también Francisco Gonzalo Marín, Mi óbolo: Mis dos cultos - A la asamblea - Al sol (Ponce, Puerto Rico, 1887). Aunque en Cuba los tabaqueros se convirtieron en los líderes de los artesanos liberales y radicales, en Puerto Rico ese rol estuvo en manos de los trabajadores de la industria de la imprenta. En los años de 1890, dos trabajadores de esta industria en Ponce fundaron el movimiento socialista puertorriqueño, y los impresores, Modesto Tirado y Arturo Schomburg, se unieron a Marín y Sotero Figueroa como importantes líderes del movimiento independentista en Nueva York. Esta tendencia parece reflejar el alto nivel de alfabetización que poseían como grupo los tipógrafos (quienes tenían como oficio configurar y verificar los textos), así como sus contactos cercanos con escritos liberales (algunos de los cuales celebraban la autodidaxia) y con los autores liberales (algunos de los cuales buscaban alianzas con los artesanos).

29. Sobre el grupo mayor de intelectuales de la clase artesana, incluyendo a Tomás Carrión Maduro, Pedro Timotheé y otros, véase Ángel G. Quintero Rivera, Workers' Struggle in Puerto Rico: A Documentary History (New York: Monthly Review Press, 1976), 19. Eileen Findlay (en una comunicación personal) añade a esta lista a los hermanos Tormes de Ponce, que se convirtieron en abogados, feministas y defensores del movimiento laboral. Sobre los médicos Tizol y Barbosa, véase Roberto Todd, Patriotas puertorriqueños: Siluetas biográficas (Madrid: Ediciones Iberoamericanas, 1965), 68-9. Véase también "Un hombre del pueblo, José Celso Barbosa", para A. S. Pedreira, en José Celso Barbosa, La obra de José Celso Barbosa, vol. 1, ed. Pilar Barbosa de Rosario (San Juan, Puerto Rico, 1937).

30. Sobre las divisiones dentro del movimiento autonomista, ver, por ejemplo, Germán 


\section{LIBERALISMO PARDO: MÉRITO, CASTA Y FAMILIA}

Como era quizás de esperarse, el grupo de intelectuales de color, que trabajaba en el establecimiento tipográfico El Vapor, no buscaba crear una alianza basada en una identidad racial compartida con las decenas de miles de trabajadores negros que vivían cerca de Ponce. No proponía representar las opiniones de la raza negra completa o, como sí hicieron sus contrapartes cubanos durante las décadas de 1870 y 1880 , o sus contrapartes brasileños en las décadas de 1910 y 1920, representar los intereses de una respetable "clase de color". Tampoco intentaron hablar en nombre de una clase trabajadora multiracial, como lo hicieron una década después en Ponce los tipógrafos José Ferrer y Ferrer y Ramón Romero Rosas. Por el contrario, Sotero Figueroa y Ramón Marín adoptaron voces literarias y editoriales desprovistas de cualquier marca de raza, casta o clase. En palabras de Figueroa, se presentaron a sí mismos como "defensor[es] incansable[s]" de los intereses de la "agricultura, industria y comercio", que veían como los intereses generales de Ponce y de Puerto Rico, y como árbitros del buen gusto, la belleza y la inteligencia. Ponce, el mayor centro de comercio en la isla durante la época, era el eje de la industria azucarera puertorriqueña en declive, y del floreciente comercio del café. En las últimas décadas del siglo XIX, la ciudad contaba con una pujante sociedad civil dominada por los hacendados, que aspiraban al modelo de riqueza y modernidad desarrollados en otras ciudades principales del Atlántico. Estos hacendados, con la ayuda de los intelectuales locales, construyeron un centro de la ciudad deliberadamente aristocrático, con carreteras pavimentadas, plazas iluminadas, una arquitectura elegante y el ornamentado Teatro La Perla. Al mismo tiempo, los intelectuales ponceños trataron de construir instituciones cívicas, dedicadas a la ilustración y el progreso, que incluían escuelas, periódicos, una biblioteca y un salón de lectura, una Feria y Exposición de la Ciudad (1882) y hasta una caja de ahorros. Marín y (con mucho menos éxito) Figueroa trataron de insertarse en la esfera pública de la ciudad ${ }^{31}$.

En sus roles como publicistas y promotores cívicos, Figueroa y Marín, tal como habían hecho sus mentores Acosta y Baldorioty, adoptaron posiciones que se enfocaban mayormente en lo que ellos llamaban la civilización moderna, una constelación que incluía el dinamismo económico, el trabajo político efectivo y el avance tecnológico. Por ejemplo, cuando los proyectos de provisión de agua o de iluminación pública en Ponce avanzaban con lentitud,

Delgado Pasapera, Puerto Rico: sus luchas emancipadoras (1850-1898) (Río Piedras, 1984), 37883.

31. Sobre Ponce y las ideologías del crecimiento urbano, raza, género y el reformismo, véase Quintero Rivera, Patricios y plebeyos, 38-98; Ileana Rodríguez-Silva, A Conspiracy of Silence: Blackness, Class, and National Identities in Post-Emancipation Puerto Rico (1850-1920) (Ph.D., University of Wisconsin, 2004), 179-286; y Suárez Findlay, Imposing Decency, 18-52, 77-109. Para la cita de Figueroa, véase El Eco de Ponce, Periódico Enciclopédico, 12 de julio de 1880. 
como solía ser el caso, o cuando aparecieron en el centro de la ciudad casuchas destartaladas, Marín preguntaba, “¿así es como debe vivir una sociedad civilizada?" Ellos contrastaban la civilización moderna, muchas veces llamada también progreso, con la inmovilidad económica, la cual atribuían al sistema político colonial. Es decir, Marín y Figueroa querían extender las definiciones de civilización moderna, un ideal que compartían con muchos de sus lectores de la elite, para que incluyera elementos específicos del liberalismo político, una serie de valores que no entusiasmaba a esos lectores o simplemente les era indiferente. Se enfocaron especialmente en la libertad de prensa y la libertad de asociación, la educación pública y en aumentar la autonomía política para la isla. También lucharon por una transición completa al trabajo asalariado, a través de la modernización tecnológica de la industria del azúcar. En su periódico, Figueroa se refería a los oponentes de dichas ideas como "partidarios del oscurantismo" ${ }^{32}$. Esta terminología nos brinda también una idea de otro de los contextos políticos importantes para Figueroa y Marín: las fuertes disputas contra el poder eclesiástico en la sociedad española. Muchos de los liberales puertorriqueños eran también miembros de movimientos espiritistas y masónicos. Estos movimientos disidentes adoptaron el lenguaje de la modernidad, el pensamiento racional, la ciencia y el progreso, a los que contrastaron con el "oscurantismo" de la iglesia. Figueroa y Marín no eran abiertamente anti-clericales. De hecho, ambos escribieron con entusiasmo sobre un grupo pequeño de sacerdotes que había ayudado a desarrollar el "progreso" de la isla mediante la creación de instituciones educativas. Sin embargo, probablemente fueron influenciados por los escritos de grupos religiosos heterodoxos y libre pensadores, y definitivamente favorecían la secularización de la educación y la creación de un registro civil de nacimientos, matrimonios y defunciones ${ }^{33}$.

Ni las nociones abstractas de civilización moderna, ni los ideales más específicos expresados por los políticos liberales y los disidentes religiosos, necesariamente incluían el concepto de igualdad racial. Sin embargo, Marín y Figueroa argumentaban que la civilización obligatoriamente significaba el abandono de los "vicios" coloniales y las "preocupaciones" como los privilegios de clase y raza ${ }^{34}$. En 1875, Ramón Marín escribió favorablemente sobre la "franqueza

32. Véase Marín en El Aviador: Periódico literario, de intereses materiales, mercantil y de anuncios, 21 de mayo de 1874; Figueroa, El Eco de Ponce, periódico enciclopédico, 12 de julio de 1880.

33. Para un contexto más amplio sobre el espiritismo y los disidentes religiosos, véase Abend, "Specters of the secular"; Álvarez Curbelo, Un país del porvenir. Sobre la visión de Marín y Figueroa de los sacerdotes como educadores y aliados de la razón, véase Marín, "A la memoria de Dr. D. Manuel Rufo" y "El Presbitero Don José María Domínguez," en Obras completas, y numerosas biografías en Figueroa, Ensayo biográfico.

34. Sobre las jerarquías raciales en las ideas de Kardec, acerca de la regeneración y la reencarnación, véase Arcadio Díaz Quiñones, "Fernando Ortiz and Allan Kardec: Trasnmigration and Transculturation" en The Cultures of the Hispanic Caribbean, ed. Conrad James y John Perivolaris (Gainesville, Florida: University Press of Florida, 2000), 9-27. Sin embargo, estas ideas 
social" de los bailes de sociedad en Ponce (con lo que parecía referirse a su apertura hacia hombres y mujeres sin pureza de sangre, como él), argumentando que el resto de Puerto Rico debía adoptar las prácticas "de una civilización adelantada que los descarte de sus puerilidades, de sus vicios, y de esos alardes vanos de un contento y bienestar mentidos". De igual manera, en 1880, cuando una institución de caridad para niñas indigentes puso a disposición dos puestos en la escuela para niñas en Ponce, con la condición de que fueran blancas y productos de matrimonios legítimos, Figueroa argumentó que la verdadera caridad "no acepta otras [j]erarquías y distinciones que las del talento". También declaró que otras formas de privilegio son la consecuencia directa de las "preocupaciones" que "la civilización hará desaparecer"35. Parece probable que esta noción de que la civilización y la modernización eran opuestas a los prejuicios sociales y raciales era central para la creación de la alianza liberal con los trabajadores urbanos, muchos de los cuales eran hombres de color. Un escritor del periódico El Artesano, publicado en Ponce en el 1874, usó el mismo lenguaje para protestar contra el prejuicio racial. "Floreciendo en nuestra sociedad se encuentra aún vigente este sistema que reconoce la superioridad de una raza sobre otra". El escritor llamó a este sistema de privilegios una "consecuencia detestable" del orden colonial, un remanente "condenado a muerte por la civilización moderna" 36 .

Probablemente, Marín y Figueroa hicieron declaraciones igual de contundentes en sus interacciones con los artesanos - y quizás Figueroa estaba realizando una aseveración de este estilo cuando fue sacado del escenario en Juana Díaz por los Voluntarios en 1883. Sin embargo, manejaron estos temas con cuidado mientras trataban de ser parte de la esfera pública burguesa de Ponce. Este toque delicado es más visible en tres escritos dramáticos exitosos que presentaban el problema del mérito en la sociedad colonial a través del lente del amor romántico. El primero de estos, una obra de teatro escrita por Ramón Marín, titulada El hijo del amor, fue presentada en el Teatro La Perla en Ponce en 1872, un año antes de la abolición de la esclavitud. La obra, escrita en verso, presentaba de manera dramática los prejuicios contra los hombres que habían nacido como hijos ilegítimos a través de la historia de un hacendado adinerado

proveyeron a los hombres negros de un repertorio que los ayudaría a criticar el sistema de castas. Adriana Chira ha encontrado evidencias de que hombres cubanos negros envueltos en el activismo racial, la educación popular y el movimiento independentista en Nueva York a finales del siglo XIX también estaban envueltos en grupos espiritistas. Pachín Marín y Figueroa trabajaron junto a estos cubanos en una serie de instituciones en Nueva York en los años 1890s. Véase Adriana Chira, Telegraphic Spirits: New Technologies of Telecommunication and Diasporic GeoTemporalities among Cuban Tobacco Workers in the US (manuscrito aún no publicado).

35. Figueroa, Ensayo biográfico, 174; Marín, Las fiestas populares, 132.

36. Carta de un artesano a su periódico. No habiendo encontrado el documento original en español, aquí incluyo una traducción al español de la cita tomada de la version reproducida en inglés en Quintero Rivera, Worker's Struggle in Puerto Rico, 185-6 
y su hijo natural. El hacendado, Don Juan, decide educar a su hijo, Eduardo, y darle su apellido, a pesar de las quejas de su esposa (la madrastra del niño). El Don Juan de la obra de Marín representaba al patriarca ilustrado puertorriqueño, que comprendía que era injusto que Eduardo sufriera el castigo social como resultado de las transgresiones de su padre. El personaje descarta los antiguos prejuicios en favor de nociones modernas de mérito. Proclama que los logros intelectuales de Eduardo facilitarían su integración a la sociedad. El joven Eduardo lo contradice, citando su propia experiencia: "Perdonad; mas, eso, padre, no es verdad en Puerto-Rico". En la colonia, "se humilla el talento y se ensalza el poderío". El padre, a su vez, lo corrige: "ya los tiempos pasaron / de sombras y oscurantismo, / y la civilización tiene asiento en Puerto-Rico. / No es pueblo ya de conquista / el pueblo que, aunque sin ruido / supo honrar el genio insigne / de su CAMPECHE"37.

Esta cita claramente describe la definición de civilización moderna de Marín, la cual premia el mérito, en oposición al oscurantismo, el cual premia solamente la clase social. La mención de Campeche, el artesano mulato, señala que el defecto que se explora a través del personaje de Eduardo es uno que incluye tanto las diferencias de raza como de clase, lo que Don Juan llama eufemísticamente "humildad". A la vez, esta conversación podría verse como una parábola sobre los límites que el discurso de la tolerancia social y racial en Puerto Rico imponía a los hombres como Eduardo (y posiblemente al mismo Marín). Eduardo plantea la cuestión de la discriminación en los círculos liberales, y alguien más poderoso que él (alguien de quien depende para vivir), le asegura que esos días han terminado. Marín ensaya estos argumentos magistralmente en la voz de Don Juan. Por el respeto que le tiene a su padre, el joven Eduardo acepta sus ideas. Sin embargo, la obra los contradice, demostrando que los tiempos de las sombras y el oscurantismo no han pasado aún. A pesar de su admiración hacia Campeche, los hacendados bien intencionados no han logrado resolver los problemas del prejuicio social en Puerto Rico.

Para demostrar este punto, y a la vez mantener cierta discreción con los hacendados, Marín desborda todas las sombras obscurantistas y todas las preocupaciones en el personaje de la esposa y madrastra celosa. Además de ser un chiste concurrente para los hombres del público sobre los sufrimientos del matrimonio, la madrastra de Eduardo se convierte en una alegoría del sistema español. Al igual que la España conservadora, ella inhibe la masculinidad del joven héroe talentoso, que se convierte en una alegoría de Puerto Rico. En primer lugar, ella impide el establecimiento de una relación propia con su padre, y le niega la herencia debida. En segundo lugar, en la escena que debe haber hecho estremecer a los hombres en el público, la madrastra se burla de la idea de que Eduardo defendería su honor, cosa que según ella no puede un hijo 
natural poseer. Más importante aún, le prohíbe a Eduardo casarse con la hermana menor de ella, de quien está enamorado. Esto le impide la oportunidad de consumar su propio estatus de patriarca a través del matrimonio honorable. Don Juan (el hacendado puertorriqueño) no es culpable de aquellos prejuicios, pero es incapaz de educar, o controlar, a su rencorosa y dominante esposa, para poder restaurar el orden a su familia. Él también es castrado por España, representada alegóricamente por la madrastra ${ }^{38}$.

El que Marín eligiera centrar su denuncia al prejuicio racial en Puerto Rico alrededor del tema de la legitimidad y no la raza nos puede revelar algunas de las dificultades que confrontó al hablar de esa categoría en el contexto de la sociedad de Ponce. El prejuicio contra las personas ilegítimas en Puerto Rico era arraigado, pero las autoridades no promovían miedos de que los hijos naturales, como clase, se rebelaran (al estilo del caso de Haití). Aun así, la ilegitimidad y el deshonor sexual nunca estuvieron separados de la cuestión de la mezcla racial. Gran parte de la sociedad suponía que la gente de ascendencia racial mixta era ilegítima (el resultado de relaciones ilícitas entre padres blancos y madres negras). Suponían también que lo contrario era la norma, y que la ilegitimidad, o el "origen oscuro", implicaban impureza de sangre. En este sentido, Marín no construye explícitamente al joven Eduardo como blanco. El personaje de la madre de Eduardo no aparece en el escenario, haciendo que la naturaleza de su estatus social y la naturaleza precisa del linaje de Eduardo permanezcan siendo un misterio. La madrastra rechaza a Eduardo no solamente porque es ilegítimo, sino también porque el linaje de su familia es desconocido. La madre abandonada finalmente aparece en Lazos de amor, la secuela puesta en escena en 1876. En esa obra, es descrita como "oscura y miserable". Esto puede ser una abreviatura poética de "miserable y de origen oscuro". Sin embargo, la palabra "oscura" podía también referirse de manera literal al color de la piel. Parece razonable imaginar que el público que conociera los orígenes de Marín se habría preguntado si Eduardo era un mulato, y habría entendido que la obra era una defensa de su derecho al honor y al amor, a pesar de esa posibilidad. Al igual que la mención de la "humildad" de Campeche, la historia de Eduardo parece simbolizar la oposición al prejuicio racial, sin nunca decirlo directamente ${ }^{39}$.

Aún cuando delicadamente insinuaba el problema de la raza en la presentación del personaje principal, Marín insertó mensajes abiertamente antiracistas en la obra, a través del personaje de un esclavo anciano, Pedro. En la superficie, Pedro parecería, más que nada, un estereotipo racista. Él exhibe muchos de los manierismos establecidos en el teatro popular antillano de

38. Para una demostración sobre cómo esto encaja con las visiones liberales sobre la familia y la educación de las mujeres, véase la reseña aprobadora de Mario Braschi de Hijo del amor, publicada en el periódico de Acosta y Sancerrit, El Progreso, reimpreso en Marín, Obra completa, 565. 38. Sobre la pregunta del honor de Eduardo, véase Marín, Obra completa, 466.

39. Marín, Obra completa, 565. 
lo que era un esclavo. El esclavo cómico, al igual que la figura de la esposa agobiante y hostigadora, sirven para establecer una perspectiva sobre raza y género compartida entre la elite masculina que asistía al teatro y el escritor de la obra, quien era el producto de la unión de un hacendado y una esclava doméstica. Quizás la idea de compartir un chiste con su público, a costa del personaje del esclavo, sirvió para establecer cierta distancia entre él y la experiencia de la esclavitud. Pero, mantenida a distancia, la historia secundaria de la obra acerca de la esclavitud proveía un espacio seguro en el que podía denunciar el prejuicio racial. $\mathrm{Al}$ responder a un comentario de pasada de su dueña, Pedro ofrece una reflexión poética sobre las capacidades sentimentales de los negros. Pedro le dice: "Esto decís olvidando / que tras la piel de mi cuerpo, / late un corazón señora / igual parecido al vuestro".

Existe una interesante ambivalencia en la forma en la que Marín trata ambos temas, prejuicio y raza. Por un lado, parece querer a toda costa separar la figura autobiográfica, y su propia identidad como escritor, del problema general de la negritud, la cual estaba estrechamente ligada a la esclavitud. Por el otro, la esclavitud era una metáfora común usada por los liberales puertorriqueños para explicar la opresión, lo que significaba que no solamente le servía para criticar el prejuicio racial en forma directa, sino que también servía para establecer paralelismos entre la maldad ya reconocida de la esclavitud y las otras injusticias coloniales. Luego de haber creado el personaje cómico de un esclavo, utiliza nuevamente esta figura para introducir una segunda historia de amor, "una pasión que nació del África, bajo el cielo", y que fue deshonrada por el cautiverio y esclavitud de Pedro. Al igual que el prejuicio prohíbe a Eduardo a casarse con el amor de su vida, el cautiverio impide que Pedro se pueda casar con el suyo. Ambos quedan impedidos de ser hombres, de consumar sus amores románticos, debido al oscurantismo del sistema colonial opresivo.

Para subrayar el paralelismo, en la escena final de la obra, ambas historias se conectan. Don Juan anuncia que enviará a Eduardo a realizar estudio en España, esperando que con un diploma universitario europeo, el joven pueda limpiar la deshonra de su nacimiento. Antes de partir, el ilegítimo Eduardo abraza a Pedro, el esclavo anciano, condenando la inmoralidad de su "condición". Luego abraza a Ana, su madrastra intolerante, perdonándola por sus malos tratos. En estos dos abrazos, actuados en el contexto del breve periodo de reformas liberales en España, Marín recrea el cuadro de una familia puertorriqueña esperanzada con la eventual resolución pacífica de dos problemas sociales interrelacionados: el prejuicio social y la esclavitud. En la secuela, Lazos de amor, una segunda solución es descubierta tras la muerte inesperada de la madrastra y la decisión de Don Juan de encontrar a la madre de Eduardo para casarse con ella, así legitimando al joven. La solución al drama de la familia puertorriqueña termina siendo no el fin del prejuicio contra las personas ilegítimas y no blancas, sino la legitimación 
de ellos a través del triunfo del amor romántico sobre los prejuicios contra el matrimonio desigual ${ }^{40}$.

Luego del éxito teatral de Marín con El hijo del amor y Lazos de amor, Figueroa también abrazó la oportunidad de convertirse en dramaturgo, al escribir el libreto de una zarzuela puesta en escena en el Teatro La Perla en 1881. El músico y compositor pardo Juan Morel Campos escribió la música. El argumento de Figueroa en la obra, Don Mamerto, se acerca al modelo creado por Marín, concentrándose en el fallido amor entre un joven criollo digno y una mujer cuya familia (al igual que la sociedad puertorriqueña) injustamente objeta su amor. Luis, el protagonista, es un joven liberal que acaba de regresar después de culminar sus estudios universitarios en España. Es un abogado, considerado honorable y talentoso. Sin embargo, los prejuicios políticos que presenta el padre de su enamorada contra él, le prohíben convertirse en un patriarca y casarse con su verdadero amor. El padre, Don Mamerto (cuyo nombre significa imbécil), es una burla de un oficial gubernamental cobarde y leal al sector conservador. Sus prejuicios contra Luis ni siquiera son honestos. No están basados en desacuerdos reales, sino en cálculos políticos pueriles y oportunistas. La asociación con un liberal podría llevarlo al fin de su carrera política y la ruina económica. En la oposición de Don Mamerto a la pareja, Figueroa dio voz a la misma queja elaborada por Marín en sus trabajos previos; que el mérito intelectual no implicaba mayor avance (o incluso seguridad) social en el sistema colonial. El envejecido político reflexiona que "el saber es un alimento muy poco nutritivo para el estómago”. Aunque admira a Luis, objeta su relación amorosa porque piensa que "Luis, con toda su ciencia, ya tiene para morirse de hambre”. Por otro lado, existían rumores de que Luis había vuelto de Madrid con importantes contactos políticos. Esto casi causa que Don Mamerto reconsidere, "porque hoy valen más los empeños a[j]enos que los méritos propios". Este conflicto es resuelto, al final, con una victoria electoral de los liberales y el nombramiento del joven a un alto puesto en la nueva administración. Entonces, Mamerto consiente el matrimonio ${ }^{41}$.

Al igual que Marín, Figueroa y Morel Campos tomaron lo que aparenta ser una decisión conspicua de contar las historias de sus propias hombrías injustamente estropeadas, sin hacer referencia directa a los conceptos de raza y clase.

40. Marín, Obra completa, 443, 59, 75. Sobre las actuaciones de artistas blancos cubanos con caras pintadas negras en el teatro bufo del siglo XIX, véase Robin Moore, Nationalizing Blackness:Afrocubanismo and Artistic Revolution in Havana, 1920-1940 (Pittsburgh: University of Pittsburgh Press, 1997), 41-61; y Yeidy M. Rivero, Tuning out Blackness: Race and Nation in the History of Puerto Rican Television (Durham, NC: Duke University Press, 2005), 32-5. Tropas cubanas de bufo llegaron a visitar Ponce en los 1870s y 1880s, y Figueroa estuvo entre el público. Véase el informe sobre los "BUFOS CUBANOS" en el periódico de Figueroa El Eco de Ponce, 19 de julio de 1880 .

41. Sotero Figueroa y Juan Morel Campos, Don Mamerto, zarzuela en un acto (Ponce, Puerto Rico, 1886). 
El héroe de Don Mamerto no tiene "defectos" sociales evidentes, más allá de ser liberal y no poseer riquezas. Esto es aún más interesante tomando en cuenta que, supuestamente, Morel Campos estaba enamorado de una mujer llamada Mercedes Arias, y su familia objetaba la relación debido a que lo veían como alguien de clase baja. Su "amor imposible" fue la inspiración para varias de sus danzas. Es difícil imaginar que las similitudes entre sus historias personales, las danzas y esta zarzuela no fueran obvias para Figueroa y Morel Campos. La decisión que tomaron de no producir una zarzuela que trataba abiertamente sobre la relación amorosa entre un artesano (por no mencionar, un artesano pardo) y una mujer blanca de clase alta, probablemente nos dice algo sobre las restricciones bajo las cuales trabajaban. La sociedad ponceña toleraba el matrimonio de Figueroa con una mujer blanca y las canciones populares de Morel Campos sobre amores prohibidos. El teatro y la música caribeña tenían también una larga tradición de contar amores entre hombres blancos de la elite y mujeres mulatas. Pero la historia del romance entre un plebeyo (especialmente uno identificado como negro o mulato) y una mujer de la elite era quizás aún demasiado difícil de tolerar para el público del Teatro La Perla. Sin embargo, esto no debe llevarnos a concluir que la obra no contenía mensaje alguno acerca de la igualdad racial y de clase. El hecho de que dos hombres que provenían de la clase artesana, ambos con orígenes raciales mixtos, hayan producido un trabajo en la tradición española y la pusieran en escena en uno de los teatros más prestigiosos del Caribe, era en sí mismo una evidencia de la capacidad intelectual de los hombres de color. A la vez, el énfasis que pone la obra en el concepto del mérito, en oposición a las prácticas coloniales corruptas e idiotas, era parte de una política de igualdad social que conscientemente construyó el prejuicio racial no como un problema social particular (compartido por talentosos intelectuales no-blancos y antiguos esclavos de plantación), sino como parte y fracción de una constelación de males coloniales (compartidos por una gran gama de hombres inteligentes y meritorios dentro de la coalición liberal). Presentar un drama sobre las formas en las que la sociedad colonial injustamente impedía a los liberales talentosos ganarse la vida, no trataba solamente de esconder o desplazar las quejas sobre el prejuicio racial. Por el contrario, dicha presentación convertía el concepto del mérito en el problema central y unificador que imponía el colonialismo contra todos los hombres meritorios de la isla, tanto aristócratas como plebeyos. Clase y especialmente raza aparentan haber sido "defectos" de naturaleza diferente en Puerto Rico, incluso más peligrosos de discutir que el liberalismo o la ilegitimidad. Aun así, hombres como Figueroa parecen haber creído que la defensa del mérito sobre el privilegio era una causa común de todos, y deseaban convencer a sus pares de esto ${ }^{42}$. Como publicistas y dramaturgos, Marín y Figueroa no cuestionaron las

42. Sobre los rumores de Morel Campos y Mercedes Arias, véase Luciano Quiñones, "Juan Morel Campos," La danza puertorriqueña en http://www.ladanza.com/morel.htm 
ideas de civilización, moralidad, enfermedades, vagancia y orden que los hacendados de Ponce y el Estado utilizaban para justificar los intentos de controlar a la clase trabajadora, ideas que inevitablemente estaban conectadas a nociones de raza. Más bien, afirmaron su posesión, como intelectuales, de los conceptos de civilización, moralidad e ilustración, los pre-requisitos para pertenecer a la sociedad civil liberal. Tomaron el lado del progreso en los conflictos entre espiritistas, masones y libre pensadores, y los "defensores del oscurantismo". También representaron el fin de las "preocupaciones" de clase o casta como parte de ese progreso. No denunciaron a los liberales de la elite que ofrecían gestos vacíos acerca de la paz racial y social y optaron por no resaltar y distinguir el rol de la raza en el orden colonial. En lugar de ello, participaron en el proceso de borrar las ya interconectadas cuestiones de la raza y la clase, para dar lugar a una concepción más amplia de la política liberal, capaz de defender sus propios derechos, independientemente de la clase y la raza, a la movilidad social, honor y ciudadanía-que solían enmarcar como sus derechos a ser hombres.

\section{HOMBRES DE HONOR}

A fines de la década de 1880, Figueroa, junto a Pachín Marín y otros artesanos intelectuales, comenzaron a hacer revisiones abiertas a las historias de las relaciones sociales en Puerto Rico, escritas por los liberales. Entre ellos mismos, dichos retos podrían haber sido comunes a principios de la década. Sin embargo, los escritos publicados que expresaban descontento se multiplicaron cuando los artesanos se desilusionaron de su alianza con los hacendados y profesionales en el movimiento liberal. El quiebre surgió en el contexto de las cambiantes políticas partidistas. La asamblea constituyente del Partido Autonomista en 1887 se apoyó en los seguidores de Baldorioty y en un número grande de libearales asimilistas y aristócratas. Como resultado de esta mezcla, el partido adoptó una plataforma que para Figueroa y los Marín estaba demasiado comprometida, despojada de las políticas "eminentemente democráticas" propuestas por Baldorioty. A la vez, algunos de los aliados de Baldorioty, incluyendo el comerciante Antonio Molina y el joven Pachín Marín, lideraron un esfuerzo para reclutar pequeños artesanos e incluso jornaleros a sociedades secretas anti-españolas, conocidas como Secos y Mojados y la Torre del Viejo. Emulando las estrategias de los republicanos irlandeses de principios del siglo, los miembros de estos grupos juraron un boicot a las tiendas de dueños españoles para forzar la implementación de reformas coloniales. Estimulados por las acusaciones de los comerciantes y los conservadores, en el verano de 1887, las autoridades arrestaron a Molina y algunos otros miembros de los segmentos más radicales del liderato autonomista. Mientras tanto, los guardias civiles de Ponce, Juana Díaz y Mayagüez, comenzaron a arrestar a artesanos y 
trabajadores, sometiéndolos a lo que los puertorriqueños (tomando prestado el término cubano para la tortura) llamaron "compontes". En el otoño, Baldorioty y Ramón Marín fueron arrestados al tratar de salir de la isla. Mientras que la prensa liberal en Cuba y España reseñaba la detención de cerca de una docena de líderes del partido de clase media y alta, la guardia civil maltrataba a las víctimas de la clase trabajadora con total impunidad. Miembros de la guardia civil colgaron por los brazos y piernas a Víctor Honoré, un albañil mulato de Mayagüez, por varios días, tiempo durante el cual lo golpearon con palos en su torso. A Gil Bones, un sastre mulato de Ponce, le rompieron los dedos. A un zapatero lo colgaron por los pies en un poste del telégrafo en Guayanilla. Otros hombres de clase baja, incluyendo algunos peones, fueron colgados de sus testículos o sumergidas sus cabezas en las aguas sucias de las letrinas. De acuerdo con un relato de la época, 197 artesanos pardos y morenos fueron arrestados, de los cuales 130 fueron torturados ${ }^{43}$.

Como humillaciones, estos actos parecen tener un significado más allá de la simple tentativa de extraer testimonios. Es posible que la violencia desproporcionada contra los artesanos liberales fuera un mensaje a una clase trabajadora cada vez más intranquila. Por otra parte, los registros oficiales de estos interrogatorios no muestran una preocupación particular con la posibilidad de una rebelión racial o incluso de clase. Los interrogadores no hicieron preguntas sobre organizaciones raciales, y en la mayoría de los registros judiciales-que contenían información detallada de los oficios, niveles de alfabetización y estatus matrimonial de los interrogados, e incluso si calzaban o no zapatos-no aparece identificada la raza. A pesar de que la raza y la clase influyeron en las torturas, definiendo incluso el tipo de trato que cada prisionero recibiría, los perpetradores del terror eligieron no mencionar la raza en los registros públicos de la investigación ${ }^{44}$.

Sin embargo, esta ola de torturas y encarcelamientos creó una ruptura entre el Partido Autonomista y los grupos de artesanos, lo que tuvo un efecto dramático en el desarrollo ideológico de Figueroa y Pachín Marín. Testigos señalaron a Pachín como uno de los reclutadores de las sociedades secretas que habían hecho los boicots. Él había invitado a trabajadores y campesinos a reuniones secretas y, de acuerdo a testimonios en la corte, los "forzó" a jurar en cuchillos cruzados a no tener relaciones comerciales con españoles. Enterándose

43. Para el estimado de 197 artesanos, véase Rodríguez-Silva, "A Conspiracy of Silence," 270-3.

44. Las fuentes sobre los compontes son varias, aunque interesantemente la mayoría se enfoca en el número relativamente pequeño de prisioneros de clase alta. Véase, por ejemplo, Lidio Cruz Monclova, Historia del año 1887 (Río Piedras, Puerto Rico: Editorial Universidad de Puerto Rico, 1958), que también cubre la asamblea autonomista de 1887. Para una descripción del trato "civilizado" a los caballeros apresados, al igual que algunas descripciones de las atrocidades cometidas contra los plebeyos, véase Eduardo Neumann Gandía, Verdadera y auténtica historia de la ciudad de Ponce (San Juan, Puerto Rico: Editorial ICP, 1987), 228-41. 
de que estaba en la mira para ser arrestado, se escapó a República Dominicana. Figueroa mantuvo vivo el periódico de Baldorioty hasta que las autoridades lo cerraron. Luego ayudó a los trabajadores arrestados a comparecer ante la corte para retractarse de los testimonios que habían sido forzados a dar y denunciar los abusos de la guardia civil. Aureliano Maguano, un residente de Mayagüez, "[h] ombre ignorante que no s[abía] leer ni escribir", invitó a "Don Sotero Figueroa" y a varios otros hombres a la corte a que lo acompañaran a brindar su retracción, porque de otra manera, alguien, según declaró: “bien pudiera, abusando de mi incompetencia, anular el acto reparador que propongo con este escrito". Sin embargo, para sorpresa de Figueroa, los nuevos líderes del Partido Autonomista comenzaron a distanciarse de los trabajadores no-blancos como Maguano. Luego de ser liberado de prisión, un ya enfermo Baldorioty, renunció a la presidencia del partido y el liderato quedó en manos de uno de sus oponentes, Francisco Cepeda Taborcias.

En la superficie, la diferencia más grande entre las dos facciones estaba en la defensa de la asimilación (favorecida por Cepeda) versus el autonomismo (favorecido por Baldorioty y sus seguidores). Sin embargo, como han señalado las historiadoras Astrid Cubano Iguina e Ileana Rodríguez-Silva, este cambio en el liderazgo también marcó el quiebre de la alianza de los aristócratas liberales y las organizaciones de artesanos. En 1890, un periódico obrero publicó una crítica al movimiento liberal. El autor señalaba que los liberales habían tomado el crédito por la abolición, demandando expresiones eternas de gratitud de parte de los artesanos (nótese que el concepto de clase "artesano" tiene también claras connotaciones raciales) por el logro. Pero, en realidad estos liberales eran "mandarines modernos" a los que los artesanos no debían nada. El periódico de Cepeda respondió con una historia llamativa de los eventos de 1887. Su Revista de Puerto Rico explicó que los excesos del radicalismo de los artesanos (con lo que probablemente se refería a los boicots y las sociedades secretas), y no la timidez de la elite, pusieron en jaque la alianza entre liberales y artesanos. Esos excesos fueron los responsables de la ola de represión sobre los trabajadores y el liderato inocente del movimiento autonomista en 1887: más aún, la subsiguiente protesta de los trabajadores amenazaba con una repetición de esos eventos. Trayendo de vuelta los fantasmas de Haití y Cuba, el periódico liberal alertó que bajo el "pretexto" de la lucha de clases, los trabajadores estaban a punto de "encender una guerra racial, tan sangrienta como la que sucedió en las vecinas Antillas" y que, como en 1887, "los pobres y mal aconsejados hombres de color" iban a terminar "pagando el precio" 45.

45. Sobre la participación de Marín en las sociedades secretas, véase Coll y Toste, "Francisco Gonzalo Marín", 220-1; y "Ampliación a la declaración del paisano don Julián Figueroa," AGPR Componente 1887, Caja 107, Pieza 6, 48-9. Sobre la participación de Figueroa, véase el testimonio de Aureliano Manguano ante la Exma. Real Audiencia, Ponce, 24 de noviembre de 1887. Para una descripción excelente y elocuente de las torturas desde el punto de vista de un ar- 
Figueroa, Pachín Marín y sus aliados expresaron sus diferencias con la dirección que estaba tomando el liderato autonomista en cuanto al tema de la masculinidad, el tema que unificaba sus ideales sobre raza, clase y honor puertorriqueño (cada vez más expresado en términos nacionalistas). Argumentaban que los hombres reales seguirían luchando a favor del proyecto radical por la autonomía y las libertades civiles, sin rendirse ante la primera ola de opresión. En 1887, Baldorioty supuestamente declaró: "Cuando salga de este encierro, si es que salgo, continuaré predicando la autonomía, y si los hombres temen, la predicaré a las mujeres". Desde el exilio en París, Betances le escribió a Ramón Marín en 1888, informándole que había recibido una avalancha de correspondencia de puertorriqueños en el exilio presionando al liderato liberal a "salvar la dignidad del país". Betances le mencionó que en estas cartas no recomendaban tener "tanta mansedumbre", sino que insistían a los puertorriqueños en que formaran "corazones varoniles". Estos llamados a la construcción de ciertas formas de virilidad, eran parte de un conflicto emergente sobre jerarquías raciales y de clase dentro del movimiento liberal.

Pocos años después de los compontes, el poeta y periodista Luis Muñoz Rivera venció a sus oponentes para convertirse en el líder del Partido Autonomista. Aunque no condenó completamente los boicots, los vio con condescendencia, catalogándolos como "el entusiasmo irreflexivo, la sencilla inexperiencia, el exaltado patriotismo de algunos liberales". Muñoz intentó reconstituir la alianza con la clase trabajadora. Apelando a los trabajadores rurales (en vez de a los artesanos urbanos), su discurso enfatizaba formas de violencia y masculinidad inherentes a su experiencia, lanzando retos a duelos y participando en peleas de gallos. Sin embargo, en sus discursos para los trabajadores rurales, abogó a favor de la docilidad de aquellos. Planteó una visión de armonía social construida sobre las bases de una relación jerárquica entre el líder carismático (él mismo) y las masas rurales. Argumentó que, en el caso de la clase trabajadora, su honor y masculinidad no requerían una rebelión contra las ofensas y la opresión. En palabras de Rozendo Matienzo Cintrón, la aliada principal de la campaña de Muñoz para obtener el apoyo de la clase obrera rural, la mas-

tesano educado, véase el testimonio de Víctor Honoré, un maestro albañil de Mayagüez. Ambos se encuentran en el AGPR Componte 1887, Caja 107, Pieza 8. Conspiraciones más pequeñas, mayormente rurales, y otras sociedades secretas continuaron operando durante la década de 1890, como continuaron los compontes periódicos contra los jornaleros. Estos estuvieron probablemente motivados por el sistema de trabajo y deuda construido por los comerciantes en las áreas agrícolas, y pueden haber sido precursores de las partidas sediciosas que aparecieron en 1898. Véase Delgado Pasapera, Puerto Rico, 428; y Fernnado Picó, 1898: La guerra después de la guerra (Río Piedras, Puerto Rico: Ediciones Huracán, 2004 [1987]). Sobre los intercambios entre trabajadores y liberales, véase el Boletín Mercantil, 22 de junio de 1890, citado en Astrid Cubano Iguina, "Political Culture and Male Mass-Party Formation in Late-Nineteenth-Century Puerto Rico," Hispanic American Historical Review, LXXVIII, 4 (1998), nota 32. Y la Revista de Puerto Rico, 11 y 18 de mayo de 1890, citado en ingles en Rodríguez-Silva, "A Conspiracy of Silence," 270-3. 
culinidad, no se demostraba a través de la rebelión y la sangre, sino "basta que luchemos dentro de nosotros mismos tratando de dominar y vencer nuestras pasiones, nuestros vicios, en cien batallas diarias". Para amar la patria, explicaba, "hay que amar a la familia, hay que amar la economía, la sobriedad, el orden y la sencillez de las sanas costumbres que hacen a los hombres fuertes e independientes" 46 .

El mensaje de paz social tenía también un componente racial, lo que tenía sus orígenes en las ideas sobre el concepto de raza expresadas durante la lucha abolicionista. Mientras Figueroa y otros artesanos estaban aún reponiéndose del trato que los hombres de su clase social habían recibido de parte de la guardia civil, el periodista y sociólogo Salvador Brau lideró una renovada campaña para comisionar el retrato de Rafael Cordero en el Ateneo Puertorriqueño. Brau argumentó que Cordero, el tabaquero y maestro escolar negro, debía ser recordado principalmente como símbolo de la "cordialidad", que definió la experiencia particular de las relaciones raciales puertorriqueña, "la contextura étnica de nuestro regionalismo" como puertorriqueños, y no meramente como el símbolo de las contribuciones de los artesanos a la causa liberal. Brau señaló lo que consideraba la tolerancia poco común de los miembros de la elite puertorriqueña que estudiaron en condiciones de igualdad con estudiantes pobres y negros bajo la tutela del Maestro Rafael. Cuando estos hombres se graduaron y se posicionaron en el lugar social que, por supuesto, les correspondía naturalmente, recordaron su amor a su humilde maestro y el respeto que sentían por sus compañeros de escuela. Recordando los relatos liberales de la abolición, Brau escribió que la cordialidad era también una característica de los negros puertorriqueños, los que no odiaban o resentían a los blancos. Mientras algunos autonomistas, como Cepeda, alertaron que los artesanos podrían hacer estallar una guerra racial, otros, como Brau, libraron una campaña para recordar la ternura con la que el Maestro Rafael trató a sus estudiantes de la elite "con el afecto análogo al de aquellas nodrizas esclavas que nos tutearon en la cuna cuando niños". Esta imagen de Cordero-la que articulaba la puertorriqueñidad en una primera persona plural ("nosotros") indiscutiblemente blanca y aristócrata-reforzaba, como elementos de la identidad regional de Puerto Rico, una serie particular de límites previamente establecidos a la masculinidad de las clases bajas, especialmente de los hombres negros. De hecho, de acuerdo a Brau, los hombres negros trataban a los blancos no como hombres, sino como sus niñeras, pacientes y cariñosas. Puerto Rico, concluía, "que no enrojece sus páginas con los nombres de un Toussaint ó de un Dessalines, se ilumina con

46. Sobre Baldorioty, véase Cruz Monclova, Historia del año 1887, 305. Betances a Marín, 5 de junio de 1888 en Luis Bonafoux y Quintero, Betances: biografía del Doctor Betances (San Juan, Puerto Rico: Editorial ICP, 1987), 128-32. Sobre Muñoz, véase Cubano Iguina, "Political Culture," 86. Also Luis M. Díaz Soler, Rosendo Matienzo Cintrón (Instituto de Literatura Puertorriqueña, Universidad de Puerto Rico, 1960), 125. 
los destellos del espíritu bienhechor de un Rafael Cordero"47. En la lucha por el control del Partido Autonomista tras la muerte de Baldorioty, Muñoz y Brau estaban más interesados en reanudar las alianzas con la clase trabajadora que con su oponente, Cepeda, quien culpaba a los trabajadores por haber sido él arrestado accidentalmente. Brau y Muñoz ofrecían una visión de la cordialidad social y racial basada en la celebración de los trabajadores negros, "humanitarios" y pasivos. Su visión, igual que la de Cepeda, desalentaba a los artesanos de responder a las torturas de 1887 con la explosión de un radicalismo indignado.

En los últimos meses antes de partir hacia Nueva York, Figueroa ofreció una opinión disidente sobre el tema de la masculinidad y la jerarquía social en Puerto Rico. Publicó una colección de más de treinta reseñas biográficas de aquellos hombres que "más contribuyeron al progreso de Puerto Rico". La mayor parte del libro era consistente con la visión de progreso, civilización y mérito que Figueroa, Marín y otros liberales habían presentado en sus escritos por más de una década. Pero la colección incluía también pasajes extraordinarios en los que Figueroa daba vuelta al pensamiento de los liberales puertorriqueños sobre la raza. Figueroa escribió su propia biografía de Cordero, y aunque resaltó la campaña de Brau a favor del maestro, sus respectivos relatos distan bastante. Mientras que Brau presentaba a Cordero como evidencia de la composición étnica particular de la sociedad puertorriqueña, Figueroa presentaba a Cordero como prueba de la capacidad de los hombres negros de educarse, ser generosos y contribuir a la causa del progreso. En ese sentido, Cordero no era una figura que contrastaba a la de Toussaint, sino similar a la del "heroico negro dominicano". Figueroa aprovechó también la historia de Cordero para enfocar su atención en las leyes opresivas bajo las cuales los hombres negros libres habían vivido en Puerto Rico a mediados del siglo XIX. Particularmente, enfatizó las leyes aprobadas en 1848, basadas en las "ideas erróneas que entonces se tenían de los instintos de la raza africana", que legalizaban la tortura pública de hombres negros (libres o esclavos) que fueran sospechosos de insultos, amenazas, o violencia contra la gente blanca. Esto tenía una resonancia particularmente importante luego de la tortura de los artesanos de ascendencia africana en el 87. Figueroa admitió que las condiciones habían mejorado desde 1848 , pero los ejemplos que usaba para demostrar ese progreso eran algo ambiguos. Por ejemplo, mencionó un artículo suyo de 1880 en el que protesta contra la discriminación de parte de una institución caritativa local como evidencia de que el prejuicio había sido eliminado (cuando parecía estar demostrando lo contrario). En un ensayo sobre el abolicionista Ruis Belvis, clarifica aún más su opinión sobre Haití. Mientras que las autoridades coloniales y algunos liberales, como Cepeda, justificaban la represión de los artesanos como método para

47. Salvador Brau, Rafael Cordero, elogio póstumo con que se iniciará en el Ateneo Puertorriqueño la velada del 31 de octubre de 1891 (Puerto Rico, 1891; reimpreso en la Alice B. Gould Collection). 
prevenir una guerra racial, Brau y otros liberales planteaban que, debido a las relaciones raciales armoniosas que existían en la isla, los negros puertorriqueños no se rebelarían como lo hicieron los haitianos. Figueroa argumentaba que los puertorriqueños habían comprendido mal el caso de Haití. Los "crímenes" que habían cometido los manumisos en Haití no "fue por espíritu de venganza con sus antiguos poseedores y otros habitantes del país, sino porque se quiso de nuevo esclavizarlos" 48 .

En un tercer ensayo, Figueroa utilizó el viejo dispositivo del amor romántico para reelaborar la historia establecida del ícono liberal José Campeche. Al igual que otros liberales en Puerto Rico, Figueroa dependía casi exclusivamente de la biografía del pintor mulato escrita por Alejandro Tapia y Rivera en los años de 1850. La reseña biográfica de Figueroa está basada mayormente en la de Tapia, pero se aleja de esta en un pasaje genial al final, en el que describe el amor no correspondido de Campeche con una mujer que rechazó sus avances. Tapia también menciona que Campeche estuvo "apasionado desde sus primeros años de una joven de las familias principales del país", que sucumbió ante "algunas preocupaciones y otros obstáculos que aquellas sugieren". Para él, los subsecuentes votos de castidad que tomó Campeche eran señales del nivel superior de lealtad de su carácter ${ }^{49}$. Figueroa elaboró esta historia, y escribió conclusiones más contundentes. Su Campeche "dió paso en su alma al noble sentmiento del amor", siendo un hombre joven, a una edad en la que "el corazón golpea con violencia en el pecho y la sangre bulle ardiente en las venas". Él creyó, incorrectamente, que el "nombre honrado, que ya empezaba [a] enaltecer la fama, era bastante [para] borrar la diferencia de posición que lo separaba del objeto querido". Así, Campeche se convirtió en un personaje de otro drama romántico, parte de la tradición que incluía El hijo del amor y Don Mamerto. La mujer, a la que Figueroa describió como “ingrata”, representaba a la sociedad, incapaz de ver la grandeza de Campeche debido al prejuicio social. Figueroa escribió que su castigo fue que su nombre haya pasado al olvido, cuando pudo haber estado ligado a la "grandeza". Figueroa invirtió la figura de Campeche, el otro gran ícono del pensamiento racial liberal. Mientras que los liberales se apropiaban de la figura de Campeche (al igual que de la de Cordero) como símbolo de la naturaleza generalmente tolerante de la sociedad criolla, Figueroa convirtió la biografía del pintor en una “[j]usta lección que deben tener presente los infatuados y engreidos con los oropeles mundanos" ${ }^{50}$.

Poco tiempo después de la primera publicación de su Ensayo biográfico, en 1889, Figueroa partió hacia Nueva York, desde donde continuó su trabajo como tipógrafo y editor aspirante. Allí fundó y presidió el revolucionario Club Borinquen, que rompió con el Partido Autonomista para unirse con

48. "Rafael Cordero Molina" y "Segundo Ruis Belvis," Figueroa, Ensayo biográfico.

49. Alejandro Tapia y Rivera, "Vida del pintor puertorriqueño José Campeche," 504-5.

50. José Campeche y Jordan en Figueroa, Ensayo biográfico. 
el Partido Revolucionario Cubano. En Nueva York, Figueroa desarrolló una relación de "compañero privilegiado" de José Martí, igual a la que había desarrollado antes con Baldorioty. Figueroa realizó trabajos de imprenta para la publicación de Patria, el periódico oficial del Partido Revolucionario $\mathrm{Cu}$ bano, muchas veces trabajando también como editor sustituto de Martí. Figueroa actuó también como secretario del Cuerpo de Consejo del partido en Nueva York, lo que lo convirtió (junto al tabaquero Juan Fraga) en uno de los dos únicos artesanos-y uno de los únicos hombres no blancos y uno de los únicos puertorriqueños-que tenían un puesto regular en la tribuna cuando se reunía el partido. En una de esas reuniones, Figueroa declaró que luego de los compontes, había llegado a la conclusión de que no había redención para Puerto Rico bajo el sistema colonial, y también había decidido desconfiar de las alianzas con la aristocracia. Hablando al público reunido, dijo: "En las grandes conmociones por el derecho no surgen los caudillos del elemento holgado, que se encuentra perfectamente bien con el órden de cosas establecido". Ni los "infatuados ni los soberbios" ni tampoco los "sabios presuntuosos" tenían autoridad para dirigir un movimiento popular. Los verdaderos líderes surgen "de la masa que sufre, de los deheredados que llevan la inspiración en la mente, torturas en el corazón y la verdad en los labios" ${ }^{\text {51 }}$. Figueroa declaró que el mejor ejemplo de un revolucionario de la clase artesana era Jesús Cristo; un carpintero al que describió como pobre y "oscuro". Tal como lo había hecho Marín en su obra de teatro de 1876, utilizó la palabra "oscuro" de una manera que podría comúnmente significar "pobre y de origen desconocido". Es posible que él (el único hombre no-blanco en el escenario) y su público (que incluía a muchos hombres no-blancos) no le hayan dado otra interpretación a la palabra "oscuro", sugiriendo que igual que ellos, Cristo era un hombre pobre y de tez oscura. En todo caso, su Cristo era un revolucionario social que luchó a favor de un "imperio de justicia" que buscaba "abolir la ley de castas", y proponía una ideología que podía ser resumida en "tres sublimes palabras: Libertad, Igualdad, Fraternidad"52. El movimiento cubano era mucho más atractivo para Figueroa que el Partido Autonomista de Puerto Rico a principios de la década de 1890 . Sin embargo, y especialmente después de la partida de Martí de Nueva York en 1895, Figueroa y otros intelectuales artesanos se sintieron defraudados por sus aliados aristócratas y profesionales blancos dentro del Partido Revolucionario Cubano. Figueroa tenía serios problemas con la directiva del partido, particularmente en relación con lo

51. En la década de 1890, grupos artesanos, especialmente el número creciente de tabaqueros, comenzaron a adoptar ideales anarquistas y socialistas. Pero a la vez que comenzaban a articular ideas de unidad de clase, muchos artesanos y negros de clase media apoyaron a Barbosa, un médico liberal negro que había estudiado en Estados Unidos y que estaba en competencia con los socialistas y con Muñoz.

52. Suplemento no. 7 de Patria: Discursos pronunciados en la confirmación de la proclamación del Partido Revolucionario Cubano, Hardman Hall, 17 de abril de 1892. 
que debían significar, en la práctica, esos ideales de igualdad y fraternidad que defendía el movimiento ${ }^{53}$.

\section{CORAZONES MASCULINOS}

En el contexto de los compontes y sus múltiples viajes al exilio, Pachín Marín también comenzó a escribir más abiertamente sobre cuestiones de raza. En la República Dominicana, Pachín publicó críticas hacia el dictador dominicano Ulises Hereaux. Hereaux lo deportó a Curazao. Desde allí, Pachín viajó a Venezuela, donde otra vez confrontó problemas con las autoridades y fue nuevamente deportado, viajando por Martinica y Santo Tomás, antes de regresar a Ponce para reabrir su periódico, El Postillón. Desde Venezuela, le escribió a Hereaux: "tirano, entre tú y yo hay una gran diferencia: ambos llevamos sangre africana en las venas, pero tú te avergüenzas de ella y yo no". Luego publicó una serie de poemas entre 1887 y 1892, usando la metáfora del prejuicio social como el amor romántico no correspondido. A esta metáfora agregó su propia sensibilidad romántica, presentándose como un hombre menospreciado, maltratado y abusado por la sociedad. Escribió en primera persona, describiendo, en algunos casos, los cuerpos de las mujeres blancas - en un poema describe una mujer con "cuello nítido y blanco cual la nieve" y en otro, una mujer con "eburneo el brazo, alabastrino el hombro, pálido el rostro, comprimido el seno".

Inevitablemente, en sus poemas, la mujer de sus sueños lo rechazó por "rango necio" o "torpe vanidad". En uno de los poemas escribió:

dura la sociedad me ha condenado

[a] callar este amor que es fe perdida, porque tengo el semblante bronceado ...

¡porque soy de una raza maldecida!

Al igual que en la biografía de Campeche escrita por Figueroa, en la poesía de Pachín Marín la mujer cruel e ingrata representa los males de una sociedad incapaz de reconocer el mérito de los hombres negros. Escribió:

¡Acaso ante tus ojos mi alma es muda

[e] ignoras, niña, en tu razón secreta,

que bajo el bosque de mi crencha ruda

la inspiración se oculta del poeta!

53. Figueroa fue eventualmente excluido del trabajo editorial de Patria y comenzó a trabajar como contribuidor del periódico de Rafael Serra, Doctrina de Martí, que defendía, en nombre de Martí, el igualitarismo radical dentro del movimiento. Véase Hoffnung-Garskof, “The Migrations of Arturo Schomburg". 
Durante los años de 1870 y principios de 1880, Ramón Marín y Sotero Figueroa, habían narrado historias de amor que al mismo tiempo que denunciaban las maneras en que las "preocupaciones" sociales limitaban injustamente la masculinidad de sus héroes, apenas daban indicios del concepto de raza. Para finales de la década de 1880, mientras él y otros hombres no-blancos disentían de las ideologías liberales dominantes, Pachín Marín escribió abiertamente sobre la imposibilidad del amor romántico con mujeres blancas ${ }^{54}$.

A la vez, y de forma más contundente a como lo había hecho Figueroa, Pachín cuestionó las normas sociales y los discursos de paz social, que restringían las posibilidades de los hombres de clase baja en momentos de tensión social. Pachín vio más que una conexión entre las respuestas activas y "masculinas" a la violencia política, y la conducta propia masculina para responder ante los agravios personales. Para él, la pregunta mayor sobre la autonomía de la isla no podía escindirse de la rebelión contra los rituales locales de dominación, basados en la raza y la clase. El marco legal y la tradición cultural en Puerto Rico dictaban incontables gestos de sumisión por parte de los hombres de las clases bajas en la interacción con sus "superiores". La historiadora Astrid Cubano Iguina ha señalado que, durante los años de Pachín como adolescente bohemio en Arecibo, estas reglas permearon los conflictos entre la guardia urbana y los jóvenes artesanos. Durante esos años, Pachín y su hermano Wenceslao (un herrero en una plantación cerca de Arecibo) aparentan haber comenzado a reivindicar su igualdad como hombres al no aceptar las restricciones sociales impuestas en las confrontaciones públicas. En ese sentido, ambos se enfrentaron en peleas callejeras con jóvenes conservadores. En un incidente, cuando Wenceslao y un grupo de amigos fueron ordenados por un guardia civil a dispersarse, Wenceslao aparentemente trató de quitarle el arma al guardia, antes de huir en medio de la noche. En otro episodio, Wenceslao le arrancó un látigo de las manos a un capataz español, abusador, en la hacienda donde trabajaba, y luego lo usó para darle una paliza pública. Temiendo las posibles repercusiones de su violación al sistema jerárquico, se escapó a Nueva York, donde encontró trabajo en una fábrica de cigarros. Como resultado de los compontes, y mientras Salvador Brau celebraba el "espíritu de bienhechor" del maestro negro Rafael Cordero, Pachín Marín usaba su poesía para proclamar su propia inhabilidad de someterse a la dominación. Escribió:

No me defiendo. M[i] altivez me grita, y es mi altivez tirano que me manda

54. "Emilia," "Del natural" y "Un puerto" en Francisco Gonzalo Marín, Romances (New York, 1892). Interesantemente, dos décadas después, el poeta puertorriqueño negro, Luis Dessús, escribió unos versos sobre la consumación física del amor con una mujer blanca. Véase Luis Felipe Dessús, Flores y balas (estados de alma) (Guayama, Puerto Rico, 1916). 
preferir al sonrojo de una súplica el agudo dolor de una estocada. ${ }^{55}$

Pachín Marín favoreció una respuesta arrogante a los compontes y, al volver a Ponce, probablemente se haya unido a los "contra-compontes", una serie de demostraciones y protestas lideradas por su primo, Américo Marín (hijo de Ramón). Se cree que los contra-compontes comenzaron cuando unos grupos de hombres jóvenes se reunían afuera de la cárcel de Ponce, demandando la liberación de los prisioneros. Mientras se celebraba la liberación de los líderes autonomistas Molina, Baldorioty, Cepeda y Ramón Marín, la multitud se enfrentó a las tropas de la guardia civil. Para los liberales, especialmente los hombres no-blancos y los artesanos, la participación en estas confrontaciones era un acto de valentía. Cuadrillas de Voluntarios, milicias conservadoras, respondieron con una escalada de violencia contra los liberales. Dieron fuego a dos cocheros que se atrevieron a testificar sobre los abusos de la guardia civil, y atacaron brutalmente primero a Ramón Marín y luego a Pachín Marín, dándoles a ambos sendas palizas. Luego del ataque, Luis Muñoz Rivera (que se había casado con la hija de Ramón Marín, Amalia) escribió de Pachín que "la ira inflamó el cerebro", y comenzó a publicar artículos "nutridos de ideas, revolucionarias, en que bullían los fermentos del odio y se retorcían las Eumenides de la venganza con terribles contracciones". En respuesta a esto, las autoridades coloniales lo multaron y luego cerraron su periódico. Muñoz le aseguró a sus lectores que los llamados de Pachín a confrontar a las autoridades no surgían del Partido Autonomista. Eran, sin embargo, ideas promovidas por los que continuaron organizando los contra-compontes, que comenzaron a tomar un matiz más rebelde. En abril de 1888, los liberales emboscaron y dieron una paliza al infame alcalde conservador de Juana Díaz, Policarpio Echevarría, y al alcalde de Aibonito. Más adelante en el mismo año, alguien disparó y mató a un fiscal en Ponce, y una bomba explotó en la casa de un líder conservador. En 1890, Pachín se enteró de que las autoridades planeaban arrestarlo y, nuevamente, tuvo que exiliarse. Abrió un hotel en Puerto Príncipe, que pronto fue consumido por un incendio. Luego se mudó a Nueva York, donde se convirtió en un orador popular y en una figura pública, reconocido por su carácter poético como un hombre romántico, maltratado por su suerte y por la sociedad, y también por la reivindicación de su masculinidad vigorosa y "arrogante"

55. "Rima XII" en Marín, Romances. Sobre el conflicto entre Wenceslao y el capataz, véase José Limón de Arce, Arecibo histórico (Arecibo, Puerto Rico, 1938). Sobre los bohemios y la guardia urbana, véase Astrid Cubano Iguina, Rituals of Violence in Nineteenth-Century Puerto Rico: Individual Conflict, Gender, and the Law (Gainesville, Florida: University Press of Florida, 2006), especialmente 1-2, 82-102.

56. Sobre los ataques y los contra-compontes, véase Cruz Monclova, Historia de Puerto Rico (Siglo XIX), 188, 204-5. Sobre Américo Marín, véase Neumann Gandía, Verdadera y auténtica historia, 186-7. Véase también Luis Muñoz Marín, "La caída de 'El Postillón”, publicado 
Para Pachín, fue difícil compaginar el escapar de estas confrontaciones en Ponce con su personalidad pública, la que promulgaba el valor masculino ante cualquier reto. En defensa propia, escribió: "No abandono la brecha como los cobardes". Aseguró que estaba dispuesto a sufrir tranquilamente multas, prisión y hasta el exilio. "Pero, el atropello que deshonra, el insulto que infama ... ¡jamás!” Rearticuló el acto de salir de Puerto Rico como la elección de un doloroso sufrimiento por encima de un deshonor. Renunció a su "prestigio público" y a su familia, pero aseguró: “¡No quiero renunciar [a] la vergüenza!!!!" Una vez en el exilio, se vio involucrado en una polémica ad hominem con el escritor conservador Vicente Balbás Capó. Pachín concluyó la discusión entre ambos sugiriendo a Balbás "que se rehabilite como hombre de honor" enfrentándose a él en un duelo a muerte. En un poema publicado en El Postillón en Nueva York, Pachín escribió: "Hame mordido con rancor aleve / la víbora ruin de la calumnia", pero señaló que su honor quedaría rehabilitado luego del combate. "Mañana cuando suenen los clarines en campos de Borinquen o de Cuba/ veremos si la envidia se insolenta, / o si me muerde el pecho la calumnia". Es interesante ver que, aunque en sus encuentros poéticos con mujeres, aparece el problema de clase y raza de manera directa, en los poemas y discusiones sobre conflictos con hombres, Marín no hace referencia alguna a la raza. Sin embargo, sus rivales políticos sabían muy bien que él era un hombre de clase artesana y de "semblante bronceada". Con o sin la referencia de que no era blanco, la identidad pública de Pachín hizo que el reto a un duelo a muerte fuera una reivindicación de su igualdad. El duelo, una forma violenta de defender su honor, estaba reservado para los hombres que tuvieran honor que defender ${ }^{57}$.

Mientras que, en sus primeros años de exilio, Figueroa hablaba en reuniones partidiarias sobre la redención que ofrecía un Cristo quien, "pobre y oscuro", aboliría las "leyes de castas", Pachín ofrecía un ideal de redención que, si bien era heroico, se basaba en la violencia masculina. En 1893, cuando la asamblea de una reunión del Partido Revolucionario Cubano en Nueva York lo llamó a dirigirse al público, él respondió haciéndolo de forma reacia, declarando que no volvería a hablar en público y que más bien prefería "demostrar con hechos positivos el fervor de sus ideas revolucionarias", lo que significaba que "iría a combatir por la independencia de la patria hasta triunfar o morir en el intento". Varios años después, le dijo a un grupo de artesanos puertorriqueños y cubanos en Nueva York que ellos eran "soldados sin gloria, infecundos, y sin tener la satisfacción de ser un soldado que pelea por la desdichada Cuba y mi

originalmente en La Democracia, reimpreso en Juan Coronel, Un viaje por cuenta del estado (Ponce, Puerto Rico, 1891), 48-52.

57. F.G. Marín, "A mis jueces y a mis amigos," publicado originalmente en La Democracia, 17 de agosto de 1890, reimpreso en Coronel, Un viaje, 46. "Vida pública", publicado originalmente en El Postillón (1892), reimpreso en Ojeda Reyes (ed.), Peregrinos de la libertad, 233. Para el intercambio con Balbás, véase Ojeda Reyes (ed.), Peregrinos de la libertad, 218. Sobre el duelo, el honor y clase, véase Cubano Iguina, Rituals of Violence, 1-2. 
desgraciada Puerto Rico", y anunció que planeaba unirse a la lucha en Cuba, donde hombres como Antonio Maceo, herido veintitrés veces, habían "reivindicado a su raza”. Al igual que Martí, “el hombre que lo sacrificó todo”, Pachín frecuentemente adoptó una personalidad marcial y fatalista, en la cual la masculinidad y la redención no estaban basadas en la batalla victoriosa, sino en la muerte. Cuando en 1896 su hermano, Wenceslao, murió luchando en Cuba, escribió que no podía proclamarse como su hermano, "mientras no caiga yo también, inmolado por sus matadores, o no vengue su muerte contribuyendo a la redención de las dos islas tristes". Dentro del movimiento cubano, las nociones de la masculinidad estaban definidas por el sacrificio en nombre de la lucha, que iba de la mano con responder vigorosamente a una afrenta personal. Esta definición de masculinidad, al igual que la "arrogancia", nunca estuvieron separadas de las nociones de raza y de clase. Esto queda claro en uno de los libros publicados por Sotero Figueroa en Nueva York, una serie de ensayos biográficos de los héroes de la Guerra de los Diez Años, escritos por Serafín Sánchez. Escribiendo sobre el africano José Antonio Legón, Sánchez exhortó: "honrad al hombre libre que murió defendiendo la libertad de todos", y quien, por lo tanto, "vale más que todos los hombres blancos y negros que no igualaron su gloria como un verdadero hombre"58. Al igual que Martí, Pachín Marín cumplió su sueño de ser héroe y mártir. En marzo de 1896, Marín siguió a su hermano Wenceslao y a su primo Ramón (hijo de Ramón Marín, el dueño de la imprenta) a Cuba. Ramón murió en combate a finales de 1896. Después de diecisiete meses en la inhospitable manigua (una palabra que significa tanto una densa jungla como un espacio de rebelión, usado frecuentemente para referirse a los campos de batalla en Cuba), Pachín sucumbió a una fiebre en la isla de Turganó.

\section{CONCLUSIÓN}

La historia de los hermanos Marín y Sotero Figueroa nos ayudan a repensar las políticas liberales en Puerto Rico a finales del siglo XIX, especialmente la corriente ideológica del liberalismo creada por hombres de estatus bajo o incierto. Lejos de aceptar nominalmente las visiones liberales de jerarquías sociales y paz racial, estos hombres lucharon por crear un proyecto de igualdad social-y la eliminación de los privilegios basados en clase y raza a favor de un sistema que solamente reconociera el mérito individual-como aspecto central del liberalismo criollo. Esto los llevó algunas veces a disentir abiertamente so-

58. Patria, 8 de mayo de 1893, Las Dos ${ }^{\star}$ Antillas, Actas del Club Político Las Dos Antillas, 18 de marzo de 1896, Schomburg Center, New York Public Library. "Mi hermano muerto," $\mathrm{Pa}$ tria, 13 de junio de 1896. Sobre el tema del martirio, véase también el poema "Improvisación (1892)", reimpreso en Ojeda Reyes (ed.), Peregrinos de la libertad, 231. 
bre temas de clase y raza con los líderes liberales blancos. Esta estrategia queda clara en el registro público de los años posteriores al colapso de la coalición autonomista en 1887, un colapso que, al igual que la ola de represión desatada por las autoridades, tenía un importante trasfondo de raza y de clase. Quizás esas críticas tuvieron extra oficialmente una vida mucho más larga, en las reuniones de grupos de artesanos y en sus conversaciones privadas. Aún, con más frecuencia, estos liberales pardos insertaron su proyecto de equidad como parte de una afirmación general sobre la civilización moderna, sin mencionar explícitamente el concepto de raza.

Vista desde lejos, esta actitud cautelosa puede confirmar la idea, mayoritariamente abrazada por los estudiosos revisionistas de la historia de raza en Puerto Rico, que los liberales puertorriqueños impusieron un silencio total sobre los temas raciales. Sin embargo, una mirada más cuidadosa demuestra que esta historia no es tan simple. El problema de la raza no estaba centralmente articulado, pero era, tanto en la ideología liberal como en las vidas de estos hombres, un problema entrelazado y muchas veces intercambiado con otras formas de opresión colonial o marginalización, otras formas de representar la diferencia y la auto-afirmación. Casta, la condición de descendencia total o parcial de esclavos africanos, era un elemento crucial de distinción e identidad social en Puerto Rico. Pero, como ha demostrado María del Carmen Baerga, ni el concepto de casta ni el concepto científico de raza (tan común en otras partes del Atlántico a finales del siglo XIX), sirvieron como principios obvios, indelebles y organizadores de las jerarquías en las ciudades puertorriqueñas. Mientras que las políticas coloniales fueron construidas sobre las bases de una sustancial ambigüedad sobre el estatus general de las castas pardas, las prácticas diarias de identificación permitieron una flexibilidad considerable al determinar el lugar de cada individuo dentro del orden social.

Los liberales no-blancos hablaron a menudo sobre los prejuicios en contra de los artesanos o de los niños ilegítimos, en ambos casos infiriendo el tema de la raza. En algunas ocasiones, usaron las tradiciones liberales que planteaban a la esclavitud y 1 prejuicio racial como metáforas del estatus colonial de los criollos blancos, para argumentar que la eliminación del prejuicio racial era una parte esencial del movimiento a favor de los derechos de los criollos. En otros momentos, hablaron abierta y firmemente sobre casta, color, o raza.

A pesar de que favorecían el buen trato hacia las masas negras y blancas, y su elevación moral e intelectualmente, en Puerto Rico los pardos urbanos alfabetizados no estaban totalmente entrelazados racialmente con las grandes masas de trabajadores negros. Veían muy poco beneficioso la posibilidad de una alianza con esas masas, por medio de una ideología de comunidad racial. En lugar de ello, intentaron crear una comunidad con los intelectuales liberales, basada tanto en los méritos intelectuales como en la opresión colonial que compartían. Su argumento principal era que la raza debía ser irrelevante a su 
posición en una sociedad civilizada. Hablaron y escribieron, principalmente, sobre qué significaba ser hombre-sobre los problemas de ser un hombre en el contexto colonial y sobre las formas apropiadas en las que un hombre debe responder al colonialismo. Entendieron a la masculinidad plena como una que incluye el derecho a cumplir un papel apropiado en las familias patriarcales, en la ciudadanía política, y a utilizar el derecho y la violencia para defender el honor personal. En un contexto en el cual la categoría de casta no operaba como una división social simple e infranqueable, sino como parte de una construcción más amplia de honor, calidad y fama, que moldeaba derechos fundamentales de masculinidad, dichos reclamos no eran eufemismos de preguntas "reales" sobre la igualdad racial. Eran, en sí mismos, expresiones de un proyecto de igualdad social. 